\title{
Social Transfers, Changing Family Structure, and Low Income Among Children
}

\author{
by Garnett Picot* and John Myles**
}

\author{
No. 82 \\ 11F0019MPE No. 82 \\ ISSN: $1200-5223$ \\ ISBN: 0-662-21741-1 \\ 24F, R.H. Coats Building, Ottawa, K1A 0T6 \\ *Business and Labour Market Analysis, (613) 951-8214 \\ Facsimile Number: (613) 951-5403 \\ ** Pepper Institute on Aging, Florida State University
}

September 1995

Wendy Pyper provided excellent research support, as always, and the paper benefitted from very useful suggestions by René Morissette

This paper represents the views of the author and does not necessarily reflect the opinions of Statistics Canada. 


\section{ABSTRACT}

Our aim in this paper is to resolve a paradox. Since the 1970s, there has been a downward secular trend in the average real and relative earnings of young adults under the age of 35 . Despite the fact that most young children live in households headed by adults under 35, there has been no corresponding secular rise in the incidence of low income among children. Rather child poverty has followed the usual fluctuations of the business cycle.

We show that the relative stability in child poverty rates in the face of declining labour market earnings is a result of two factors. First, the decline in market income in young households with children has been offset by rising transfers. Since the 1970s, social transfers have replaced earnings as the main source of income among low income families with children.

Second, changes in the fertility behaviour and labour market characteristics of young adults have sharply reduced the risk of young children growing up in low income households. Today's young parents are better educated, working more hours, having fewer children, and postponing childbirth until later ages when earnings are higher. Although more children do find themselves in single parent families, this change has been swamped by other changes in family patterns and labour market behaviour that have reduced the risk of child poverty.

Thus, the upward pressure on low income among children stemming from the labour market has been offset by social transfers, on the one hand, and by changes in family formation and the labour market behaviour of young adults, on the other. Except for cyclical variations, the result has been relative stability in the incidence of low income among children over the 1980s and early 1990s. Whether these offsetting patterns will continue in the last half of the 1990s remains to be seen.

Key words: Poverty; Child Poverty; Earnings Inequality; Low Income. 


\section{Introduction}

Rising inequality in labour market earnings became a characteristic feature of many western countries in the 1980s (OECD, 1993; Freeman, 1994). Associated with this development was a sharp decline in the earnings of younger workers (Davis, 1992). In Canada, for example, the real and relative earnings of workers under 35 declined between the late 1970s and 1986 and failed to recover during the economic expansion that followed (Myles, Picot and Wannell, 1988; Betcherman and Morissette, 1992; Morissette, Myles and Picot, 1994). The pattern was widespread, affecting young workers in virtually all industries and all education classes. In contrast some older adults (those not affected by unemployment) experienced a modest improvement in their labour market earnings.

The significance of these changes is magnified by the fact that the restructuring of the economic life course of young adults now appears to be relatively permanent. The decline in earnings of young adults began in the late seventies and accelerated during the recession of 1981-84. For men, the trend was not reversed during the recovery of the 1980s and in fact continued through the decade, albeit at a slower pace. Real earnings of younger women recovered somewhat over the decade, but for both sexes the earnings gap between younger and older workers widened substantially (chart 1). This occurred despite a decline in the relative number of young adults entering the labour market and a marked increase in educational levels - changes which would be expected to increase the wages and earnings of young adults. Earnings inequality within the young age groups also rose. ${ }^{1}$ Thus, among workers under 35 average real earnings fell and inequality around this declining mean rose.

Since the majority (60\%) of younger children (ages 0-6) live in households where the highest earner is under 35, we might expect the rate of child poverty to move upward as the earnings of younger adults decline. However, while the percentage of children below Statistics Canada's Low Income Cutoffs (LICOs) has risen during recessions and declined during expansions (Chart 2), there is little evidence of an upward secular trend in the percentage of low income children during this period. Some observers suggest that the value observed for 1993, which is above the highest value reported during the earlier 1981-82 recession, may be evidence of an upward trend during the 1990s. However, during the 1980s and early 1990s, the period of interest here, no such trend is evident and all of the movement appears to be associated with the business cycle.

1 The gini, a commonly used measure of inequality, increased more or less continuously from 0.427 in 1977 to 0.449 in 1989 for very young males (17-24) and from 0.270 in 1977 to 0.313 in 1989 among men aged 25-34. Inequality among young women (17-24 ) also increased. Inequality among women aged 25-34 fell largely because women working part-time were working longer hours in the late 1980s than in the earlier period, thus increasing their earning and decreasing inequality. 
Chart 1: Indexed Real Annual Earnings by Age, Men Working Full Year Full-Time

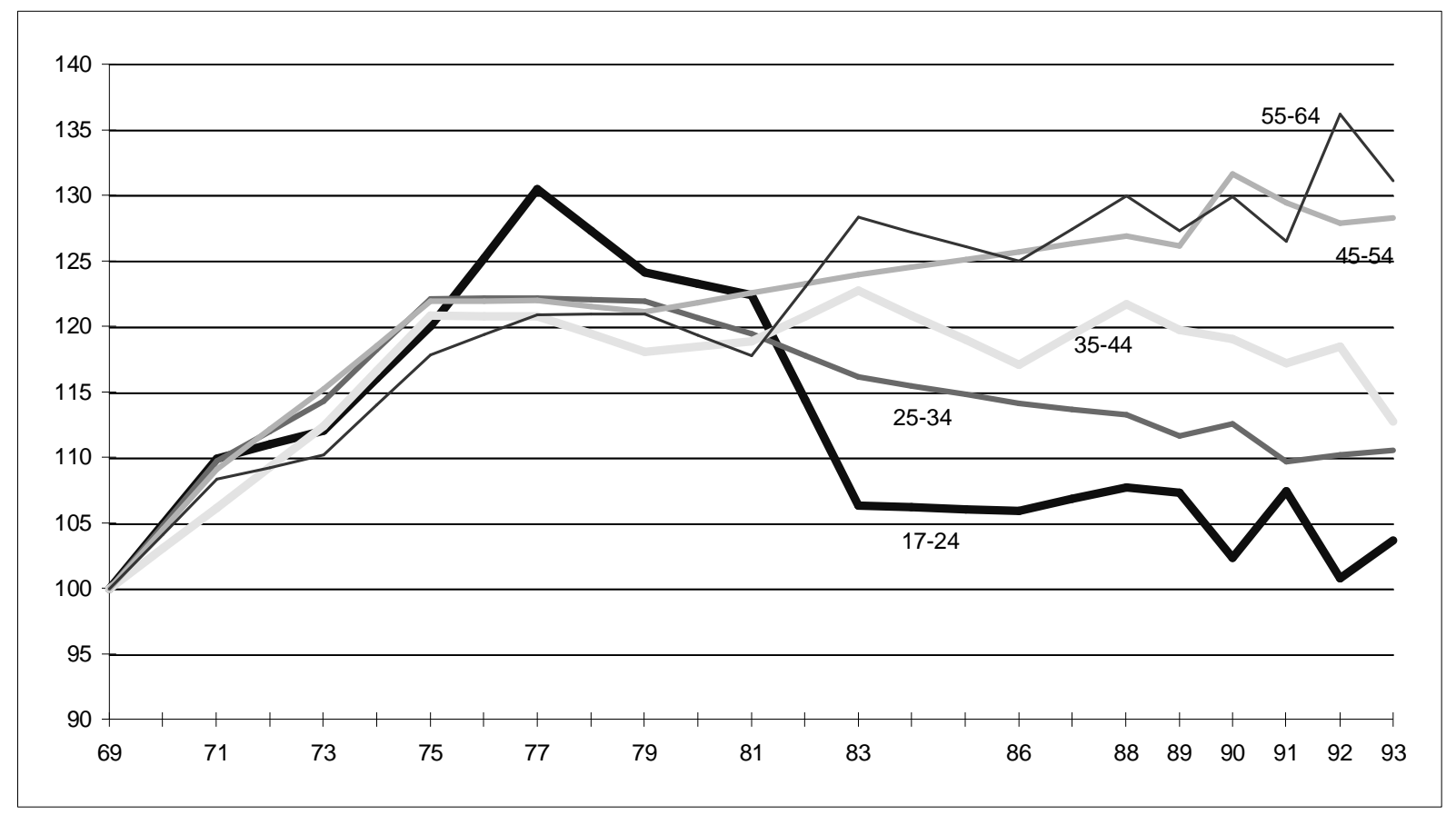

Chart 2: Rate of Low Income among Children (\% Below L.I.C.O.)

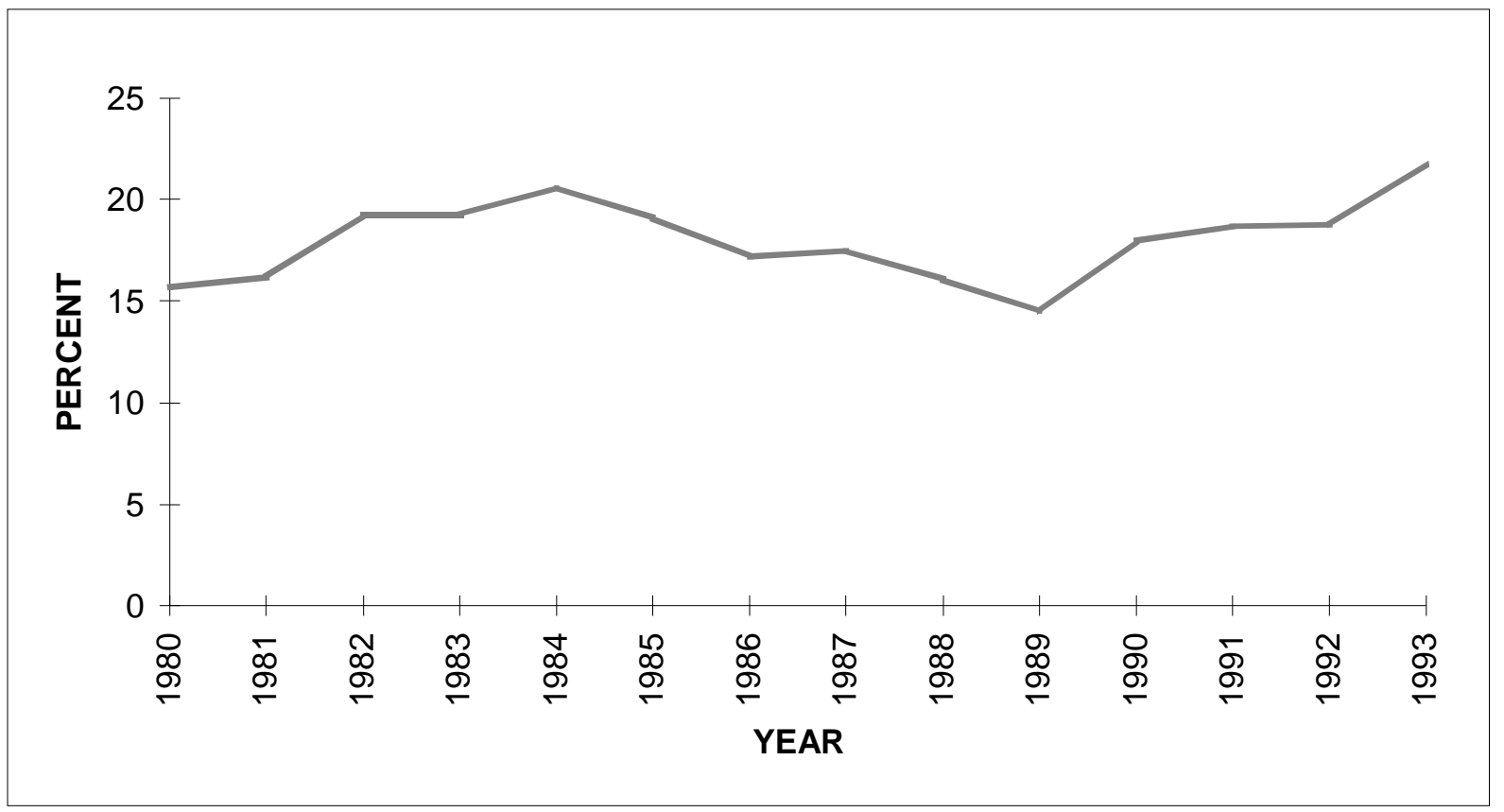


Using a somewhat different measure of low income -- the proportion of children in families with less than 0.5 of median adjusted family income -- we reach similar conclusions. ${ }^{2}$ There was a slight rise in the proportion of children aged 0-6 in low income families between 1981 and 1988 (from $14.8 \%$ to $16.0 \%$ ), offset by a decline among children ages 7 to 14 (from $14.3 \%$ to $13.6 \%$ ). Overall, however, the dramatic changes in the earnings of young adults in the past two decades are not reflected in changes of corresponding magnitude in the rate of low income among children.

The goal of this paper is to investigate this apparent paradox: long term stability in the incidence of low income among children in the face of dramatically declining relative and real earnings and rising earnings inequality among young workers (under 35). We begin by describing changes in family income by age and family type since the 1970s. We then assess the contribution of three factors to the changing economic circumstances of children: (1) declining market earnings; (2) transfer payments, and (3) the changing characteristics of families in which children live.

\section{The Changing Incomes of Young Families}

The growing earnings gap between younger and older workers is reflected in a growing gap in total family incomes between younger and older households. For example, the income of families whose highest earner is age 20-26 was 1.13 times the median adjusted income for all families in 1967 but fell to just 0.77 by 1991 (Chart 3). ${ }^{3}$ In the $27-35$ age group, relative median income also fell from a high of 1.17 in 1973 to 1.05 in 1991. The gainers were families between the ages of 35 and 54. Thus, relative median family income has been falling among young families. And since there has been little change in median income over the 1980s, this means that real median income has also been slowly falling among young families.

2 There is a variety of ways to measure low income. Family income is first adjusted for size and composition and then a cutting point in the distribution is established. Statistics Canada's Low Income Cut-Offs (LICOs) have historically been used to chart low income in Canadian families. Essentially, LICOs establish the cut-off at a level where families are spending significantly more family income on necessities (60 percent) than the average Canadian family (40 percent). A second approach widely favoured among scholars (Wolfson and Evans, 1992; Sharif \& Phipps, 1994) is to construct the distribution of family income based on adult equivalent income and to classify as having "low income" those families whose income lies below 50 percent of median equivalent income. Since LICOs are only available for distribution of total family income we use the "50\% Median" cut-off in this paper. Either method, however, yields essentially similar results (Sharif and Phipps, 1994)

Data are for census families from the Survey of Consumer Finances for the years 1967, 1973, 1981, 1986,1988 and 1991. To adjust for family size, composition and economies of scale, family income is adjusted using adult equivalency scales. These scales adjust family income for family size and composition, and convert the family income to a form of per capita income, where the income is per adult equivalent in the family. The equivalency scales allow for economies of scale in families, and hence the second person is given a lower weight than the first, under the assumption that many of the fixed costs are accounted for by the first person and hence the income of the second need not account for such costs. There are many such equivalency scales available including those implicit in the construction of Statistics Canada's low-income cutoffs. Here we adopt the "central variant" scale proposed by Wolfson and Evans (1992:46-47). The first person is given a weight of 1.0 and each additional adult a weight of 0.4 . The first and each subsequent child is assigned a weight of 0.3 except in single parent families where the first child is assigned a weight of 0.4 . 
These results, however, are for all family types combined; including those with or without children. Disaggregating by family type (Charts 4 and 5) shows that the main impact of declining earnings among the young was experienced in households without children.

We first focus on families with the highest concentration of children, those where the highest earner is between 27 and 34 years old. Real median family income remained largely unchanged for families with children between 1981 and 1988, the peaks of the business cycle. This was true for both two-parent and single parent families (Chart 4). Among two-parent families without children, however, real median family income fell by $10 \%$, and among unattached individuals by $11 \%$. Similar patterns were observed among younger families aged 20-26 (Chart 5). Thus, declining earnings among young adults expressed itself mainly through falling incomes among family units without children.

\section{Chart 3: Change in Relative Median Income, by Age of Family, Total Income}

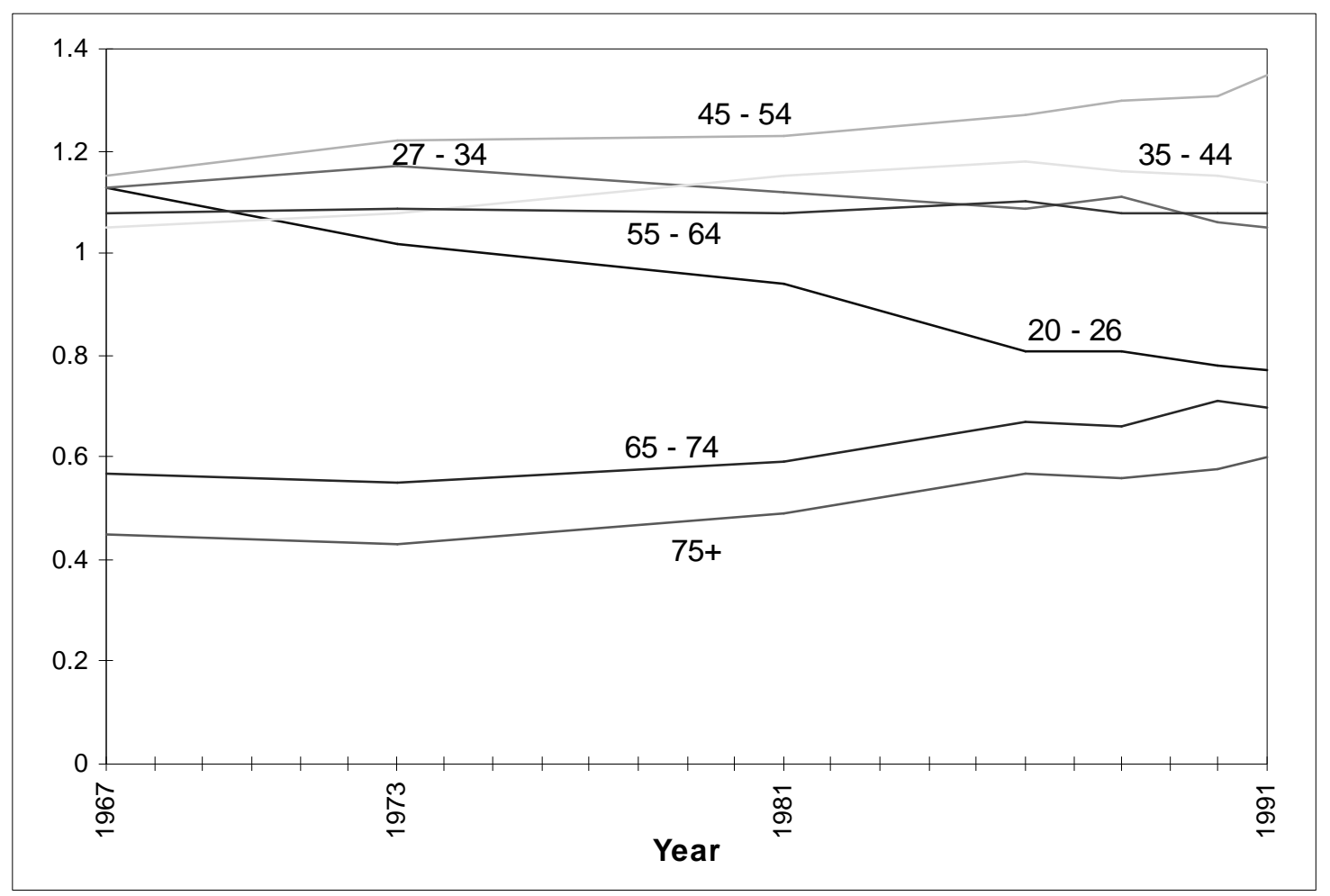




\section{Chart 4: Real Median Disposable Income (AE Adjusted) Families 27 to 34}

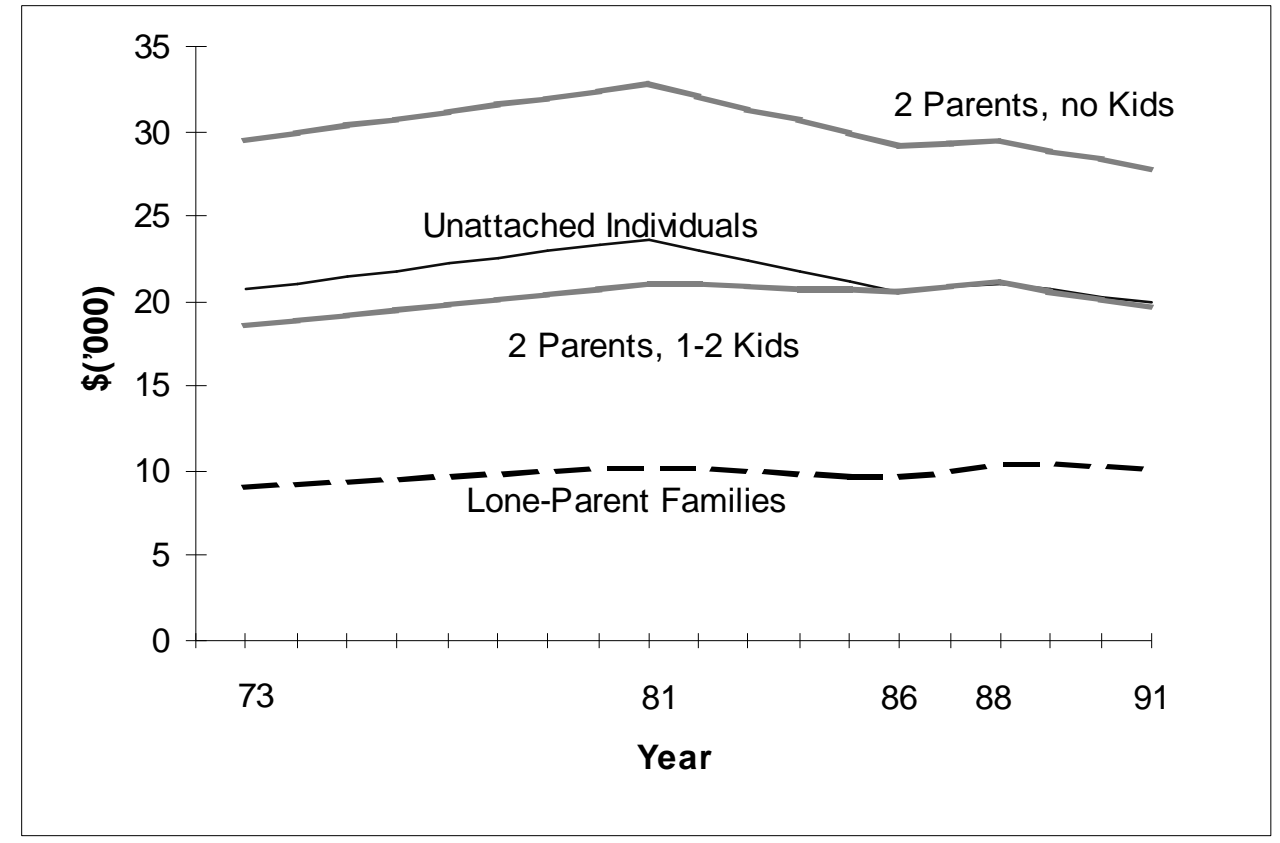

Chart 5: Real Median Disposable Income (AE Adjusted) Families 20 to 26

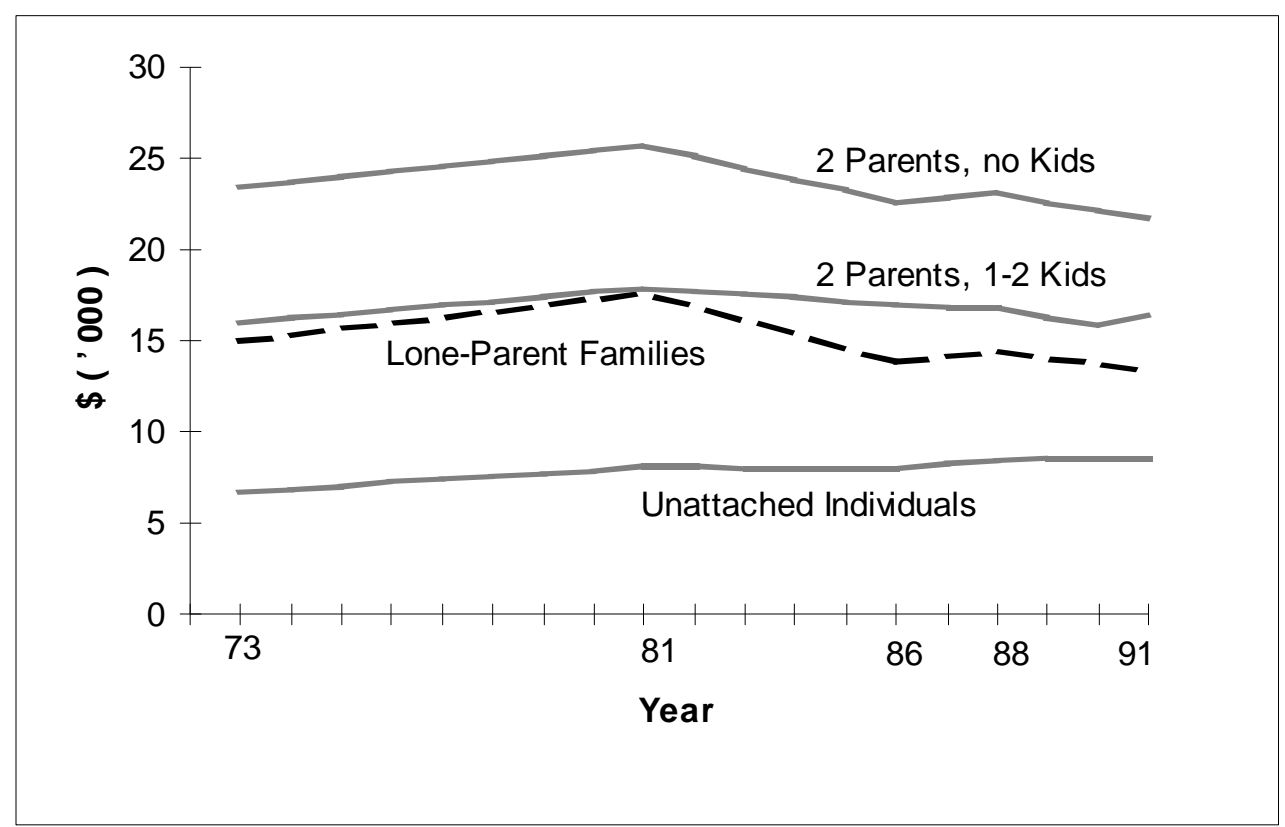


There are several reasons why young families with children may have avoided the worst impacts of the more general deterioration of the labour market conditions of young adults. First, the taxtransfer system is designed to protect families with children. The refundable child tax credit (now the Child Tax Benefit) and social assistance, for example, are triggered by low earnings among parents. We examine the role of the tax-transfer system over the 1973 to 1991 period in the next section. Secondly, partially in response to their changing circumstances, young adults are having fewer children and having them at older ages. There are also more two earner couples and young adults are better educated than in the past. These and other demographic changes that affect low income rates are taken up in section three.

\section{Taxes, Transfers and Low Income Among Children}

In this section we assess the association between the tax-transfer system, and the incidence of low income among children. In particular, we focus on the changing role played by the tax-transfer system over the 1970s, 1980s and early 1990s. First a few comments on methodology. To conduct this analysis, each individual in the sample from the Survey of Consumer Finances (SCF), the data source used here, is assigned the adult equivalent adjusted (AEA) income of the family to which he or she belongs. ${ }^{4}$ AEA income is essentially a per capita measure of family income which has been adjusted to take account of economies of scale achieved in larger families (see footnote 3 , above). Having computed adult equivalent adjusted family incomes, we compare the median incomes and rate of low income based on two different income distributions: first the distribution of income received from all market sources (before transfers and taxes) and second, the distribution generated using final disposable income (after transfers and taxes). The differences in the incidence of low income observed from the pre-tax/transfer and posttax/transfer incomes, and most importantly how these differences vary through time, is an indicator of the effect of the tax-transfer system.

Pre transfer/tax (market) income includes wages and salaries, military pay, self-employment income (farm and non-farm), investment income, private retirement pension income, and other money earnings. The composition of government transfers changes from year to year as government programs change, but post 1990 they include family and youth allowances, OAS, GIS, CPP, QPP, UI benefits, social assistance, provincial tax credits, child tax credits, federal sales tax credit, GST credit, and other government transfers. Taxes paid refer to income taxes.

It is well known that the SCF underestimates transfer income, especially income from UI and social assistance. However, the level of underestimation is quite consistent through time. Between $75 \%$ and $80 \%$ of government transfers are captured in the SCF file, and for the years in

4 Economic families are used in this section. This means that incomes from persons outside the immediate family that are related by marriage or blood are included. This is a fairly conservative approach to measuring the changing economic conditions of Canadians over time, since if relatives choose to live together in the late 1980s or 1990s more than they did in the early 1970s because of worsening economic conditions, this would not be picked up in this analysis. If census (immediate) families were employed, some relatives in the household would be viewed as unattached individuals; they are not seen as having access to the economic resources of other relatives in the household. This is not true among economic families, which are used here. Thus, the impact of behavioural changes related to the declining market incomes of the young may be understated. 
which we are most interested, notably 1973, 1981, 1986 and 1988, comparisons with other data sources indicate that SCF captured about $77 \%$ of all transfer payments. Hence our assessment of the effect of transfers is a conservative one, as we are underestimating its impact on family income, but it is consistent through time. This latter point is most important in the analysis to follow. Taxes payable reported in the SCF constitute $98 \%$ of those reported by Revenue Canada.

The comparison of the rate of low incomes on a pre-transfer and post-transfer basis is intended to describe the changing significance of the tax-transfer system over the 1973-91 period. This is a decomposition of history, not a causal analysis of the effect of the transfer system on poverty. In the absence of child benefits, for example, young parents might have increased their working hours to offset lower wages.

A frequent criticism of social transfers is that they inhibit the sort of labour market and other behavioural responses that would make social transfers unnecessary. Such claims are difficult to assess because the real world rarely provides the natural experiments that would be required to test them. Rebecca Blank and her colleagues (Blank, 1994) have recently published a series of comparative studies that refer to this issue. They conclude that the work disincentive effects of social safety nets are simply too small to generate the large changes in employment and earnings patterns of the past two decades. In an analysis of Canadian and US poverty, Hanratty and Blank (1992) conclude that behavioural responses to social transfers are likely a fairly small part of the observed differences between the countries. While such work disincentive effects exist, the question is whether they are large enough to produce the kind of changes in earnings outlined earlier. Since we do not attempt to incorporate behavioural responses in the analysis, we return to this issue in the conclusion.

Finally we should note that changes during particular time periods have somewhat different analytical significance. For example, changes between 1981 and 1991 confound long term secular trends with the short term effects of the recession that began in 1990. Child poverty, for example, typically rises during economic contractions and declines during recovery. For this reason, we give special attention to changes that occurred from peak to peak in the business cycle, notably 1981-88 (and 1973-81). This does not mean we ignore changes which occur between peak to trough in the business cycle (e.g. 1988-91). The effects of recession are quite real and often substantial, especially in the life of a young child. The point is rather to separate long-term secular trends from short-term cyclical fluctuations.

\section{Results}

Government transfers have become an increasingly important source of income for young people in general, and young families with children in particular. The relative shares of earnings and transfers in the "income package" of low income families with children were essentially inverted

\footnotetext{
After adjustments are made to the Revenue Canada figures to make the two sources conceptually comparable. In SCF an individuals taxes payable are estimated using an algorithm that essentially completes the tax form for each person based on the information available in SCF.
} 
between 1973 and 1991 (Chart 6). In families with young children (0-6) and less than half the median income, the share of disposable income from government transfers rose from $36 \%$ in 1973 , to $45 \%$ in $1981,56 \%$ in 1988, and 63\% in 1991 (Table 1). Transfers constituted one third of these families' incomes in 1973, two-thirds in 1991. The reliance on labour market earnings fell correspondingly; earnings as a percent of total disposable income fell from two-thirds in 1973 to one-third in 1991. Similar changes are observed for families with older children.

Changes in the levels of income from transfers and market sources tell the same story as changes in shares of incomes. In constant (1991) dollars, average market earnings fell from $\$ 3400$ to \$2600 between 1973 and 1991 in the families of low income children age 0-6 (Table 2) while transfers increased from $\$ 1900$ to $\$ 4600$. A similar pattern is evident among older children. For the younger children, transfers rose more quickly than earnings declined with the result that the "depth of low income" -- the difference between average total income in low income families and $50 \%$ of median income -- declined slightly (Table 2). Average total income as a percent of our low income measure rose from $70 \%$ to $83 \%$ over the period. Among older children the "depth of low income" remained constant over the period.

Most of this increase in transfer payments was associated with increasing income from the child tax credit and social assistance (Table 3). For example, among 0-6 year olds in low income families the share of income from social assistance (welfare) rose from 17\% in 1973 to $30 \%$ in 1991. The child tax credits, which did not exist in 1973, accounted for $10 \%$ of family income in 1991. Increasing UI accounted for only a very small part of the overall increase.

The increasing significance of transfer payments can be described by comparing the rate of low income among children based on market earnings (before taxes and transfers), with the rate of low income observed after taxes and transfers are included (i.e. disposable income). ${ }^{7}$ Changes in the gap between these two measures of the incidence of low income among children reflect the increasing role played by the tax/transfer system.

6 Focusing on all families with young children (not just low income families), we find that in 1973, families with 0-6 year olds depended on transfers for $6.6 \%$ of their disposable income, $8.5 \%$ in 1981, and $11.0 \%$ in 1988 .

7 That is, calculate the proportion of young children in families with incomes below 0.5 of the overall median income, where income is defined first as before tax and transfer and then after tax and transfer. 


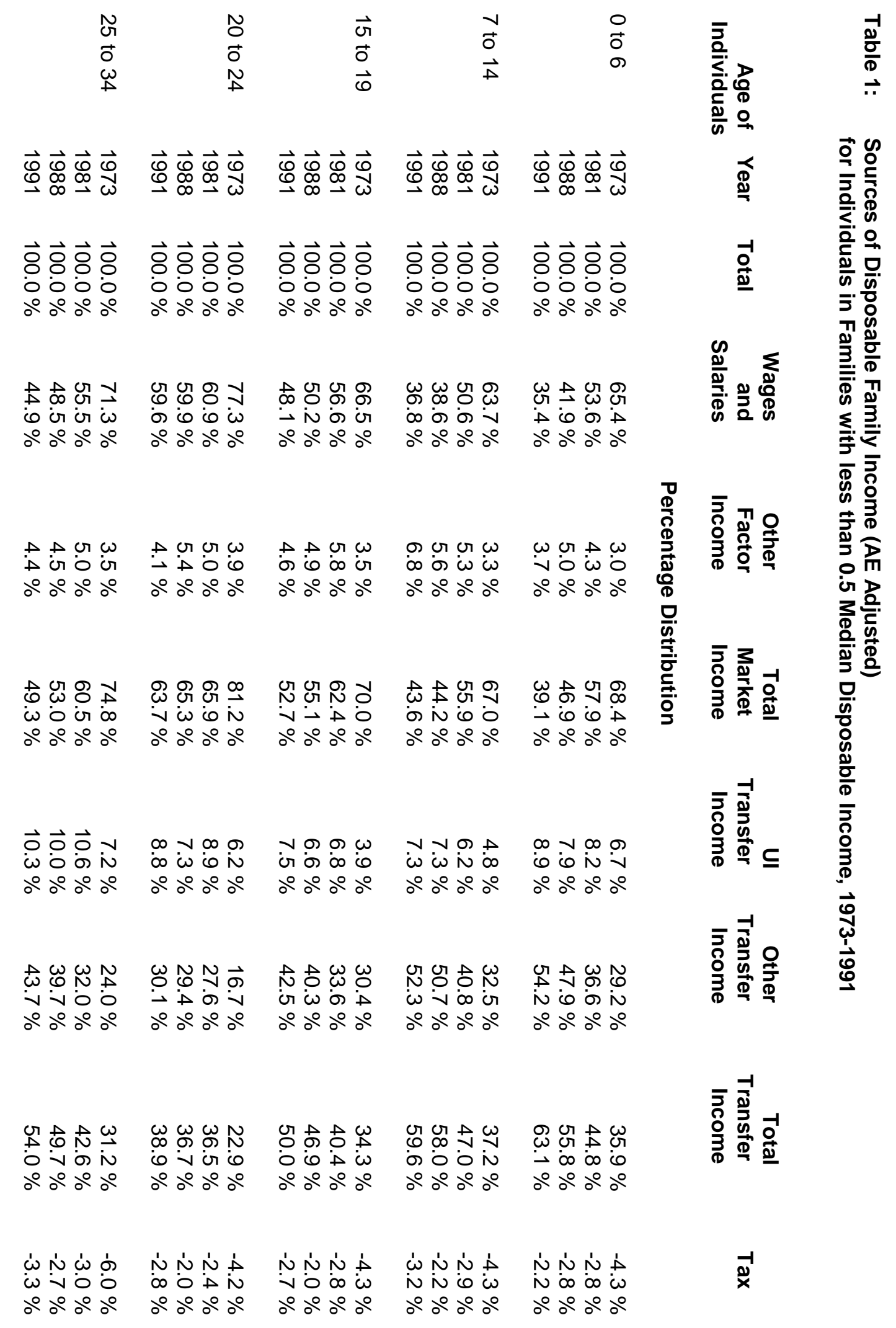


Chart 6: Source of Disposable Family Income, Children 0 to 14 in Families with $<0.5$ Median Income

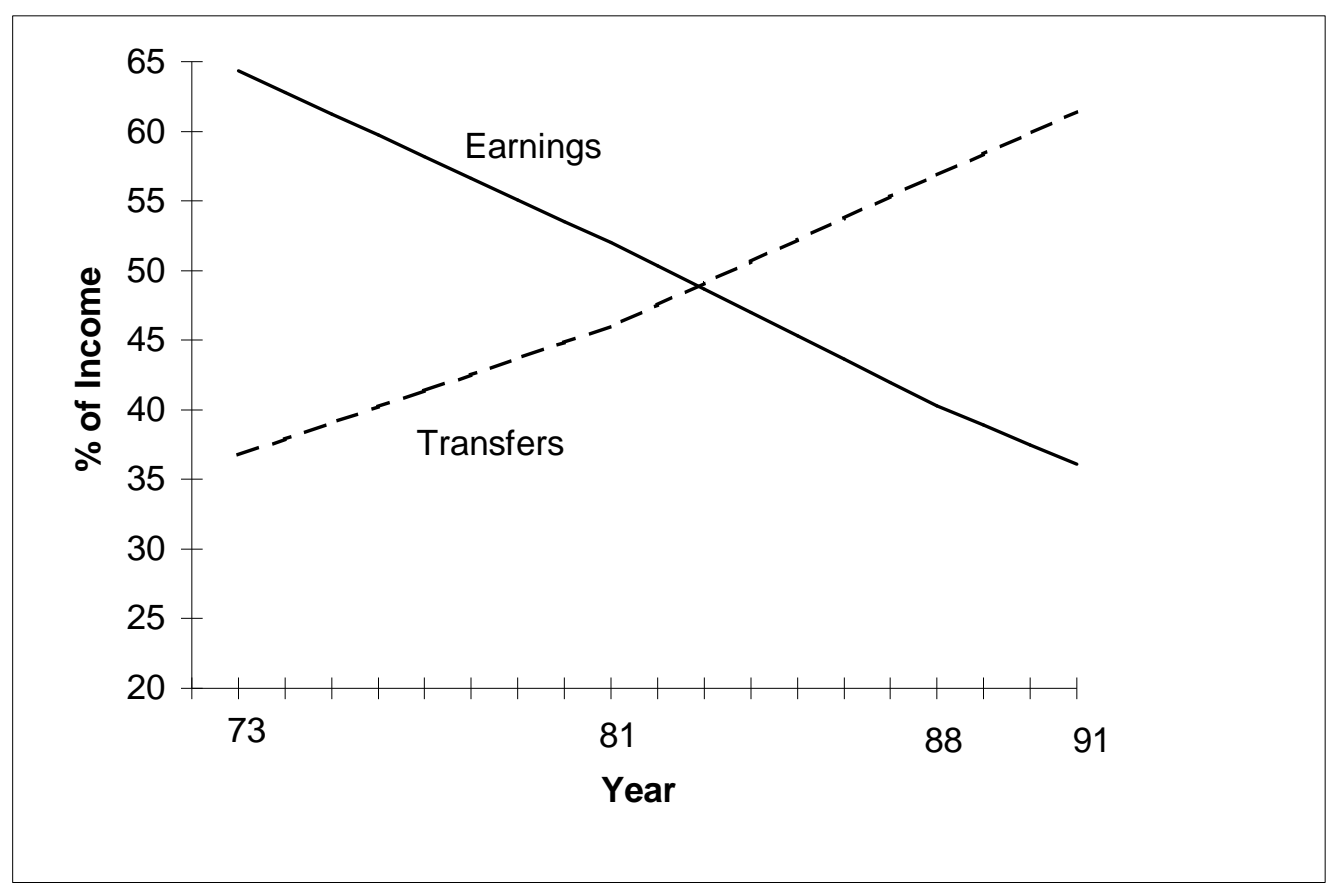


Table 2: Change in Market Earnings and Transfer Payments in Low Income Families with Children, 1973-91

\section{A. Children 0-6 in families earning $<0.5$ median income}

$\begin{array}{llll}1973 & 81 & 88 & 91\end{array}$

Average employment earnings

- in constant dollars $(000 \mathrm{~s})$

- as $\%$ of $1 / 2$ median income

$\begin{array}{rrrr}3.4 & 3.7 & 3.2 & 2.6 \\ 44 \% & 40 \% & 34 \% & 29 \%\end{array}$

Government Transfer income

- in constant dollars (000s)

$\begin{array}{llll}1.9 & 3.1 & 4.3 & 4.6\end{array}$

- as $\%$ of $1 / 2$ median income

$25 \% \quad 33 \% \quad 46 \% \quad 51 \%$

Average total income as $\%$ of $1 / 2$ median income

$70 \% \quad 76 \% \quad 85 \% \quad 83 \%$

(i.e. depth of low income)

$1 / 2$ median income (000s)

7.7

9.2

9.3

9.0

(adult eq. adj.)

\section{B. Children 7-14 in families earning $<0.5$ median income}

$\begin{array}{llll}1973 & 81 & 88 & 91\end{array}$

Average employment earnings

- in constant dollars $(000 \mathrm{~s})$

- as $\%$ of $1 / 2$ median income

$\begin{array}{rrrr}3.5 & 3.6 & 3.1 & 2.7 \\ 44 \% & 35 \% & 28 \% & 26 \%\end{array}$

Government Transfer income

- in constant dollars (000s)

$\begin{array}{llll}2.1 & 3.3 & 4.6 & 4.4\end{array}$

- as $\%$ of $1 / 2$ median income

$27 \% \quad 32 \% \quad 41 \% \quad 42 \%$

Average total income as $\%$ of $1 / 2$ median income

$\begin{array}{llll}70 \% & 69 \% & 71 \% & 70 \%\end{array}$

(i.e. depth of low income)

$1 / 2$ median income (000s)

$\begin{array}{llll}7.9 & 10.3 & 11.1 & 10.5\end{array}$

(adult eq. adj.) 

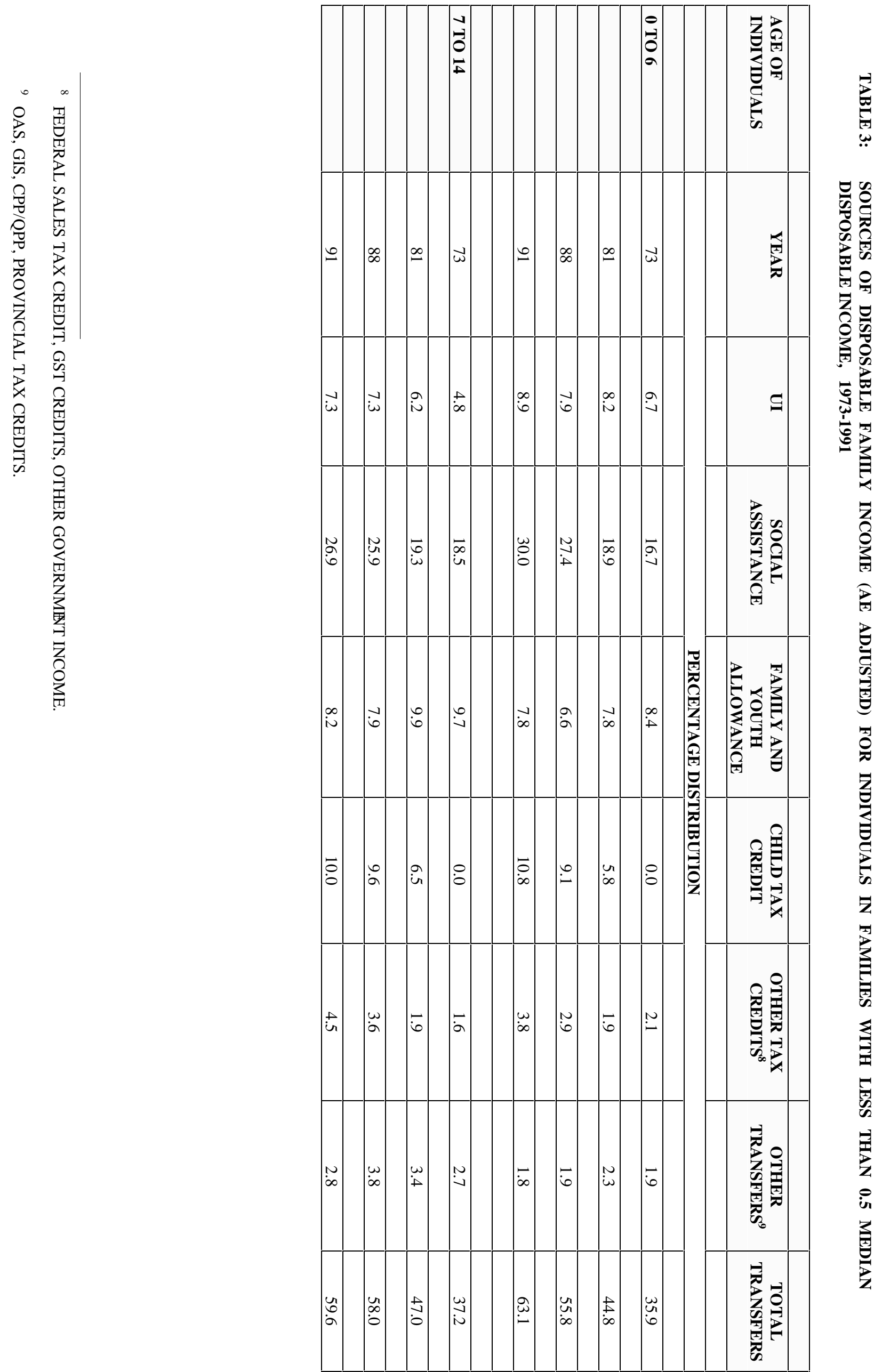
Detailed patterns in pre- and post-transfer/tax income by age are presented in Appendix Table 1. The prevalence of low incomes on a market income basis (before taxes and transfers) grew sharply among younger children (0-6) but only modestly after taxes and transfers. The incidence of low income on a pre-transfer basis rose from approximately 20 to 24 percent between 1981 and 1988 and then to 28 percent in 1991 among the youngest children, an increase of 8 percentage points. After taxes and transfers, however, the actual rate of low income rose by just over 1 percentage point between 1981 and 1988 (from $14.8 \%$ to $16.0 \%$ ) and by another half percentage point (to 16.5\%) as the recession of the nineties set in (Chart 7). Similar trends are observed for older children. The proportion of 7-14 year olds below 0.5 of the median rose by 1.4 percentage points between 1981 and 1988 based on market income alone, but actually fell 0.7 points when taxes and transfers are included.

These trends indicate two things. First, the incidence of low income is much lower after transfers than before, as one would expect. The redistribution of income does influence low income rates. Secondly, the extent of this redistribution has been increasing through the 1980s as market earnings have become a less significant share of family income among low income families. The gap between the rate of low income before and after transfers has been rising.

As expected, the prevalence of low incomes among 20-35 year olds also grew sharply on a market income basis over the 1980s, rising from 16 to almost 21 percent among 20-24 year olds and from 14 to 17 percent in the group aged 25-34. But the actual rate of low income (after transfer/taxes) increased significantly only for 20-24 year olds (Appendix Table 1). The expansion of the transfer system replaced the decline in market earnings among lower paid 25-34 years olds.

In the higher age groups, the prevalence of low incomes grew only modestly or was stable on a pretransfer basis. After transfers and taxes, however, poverty rates actually declined among the population over 45 .

In summary, declining relative earnings among young adults and increasing earnings inequality in general during the 1980s brought a rise in the percentage of Canadian children exposed to the risk of low income. This was accompanied by an increase in the role played by the transfer system. Public expenditures on social protection for the non-elderly rose from $5.7 \%$ of GDP in 1980 to $7.6 \%$ in 1990 (OECD , 1994). The combined result was more or less stable incidence of low income among children and young adults (except 20-24 year olds).

\section{Exposure to Risk of Low Income: Changing Demographics And Labour Market Characteristics of Families}

Our aim in this section is to show that transfers are not the only reason for relative stability in the prevalence of low income among Canadian children. The kinds of families in which children live today are very different from those of their predecessors of one or two decades ago. The cumulative effect of these changes has reduced the risk of poverty among children considerably. 
Chart 7: Proportion of Individuals with Family Incomes Below 0.5 Median Income, by age
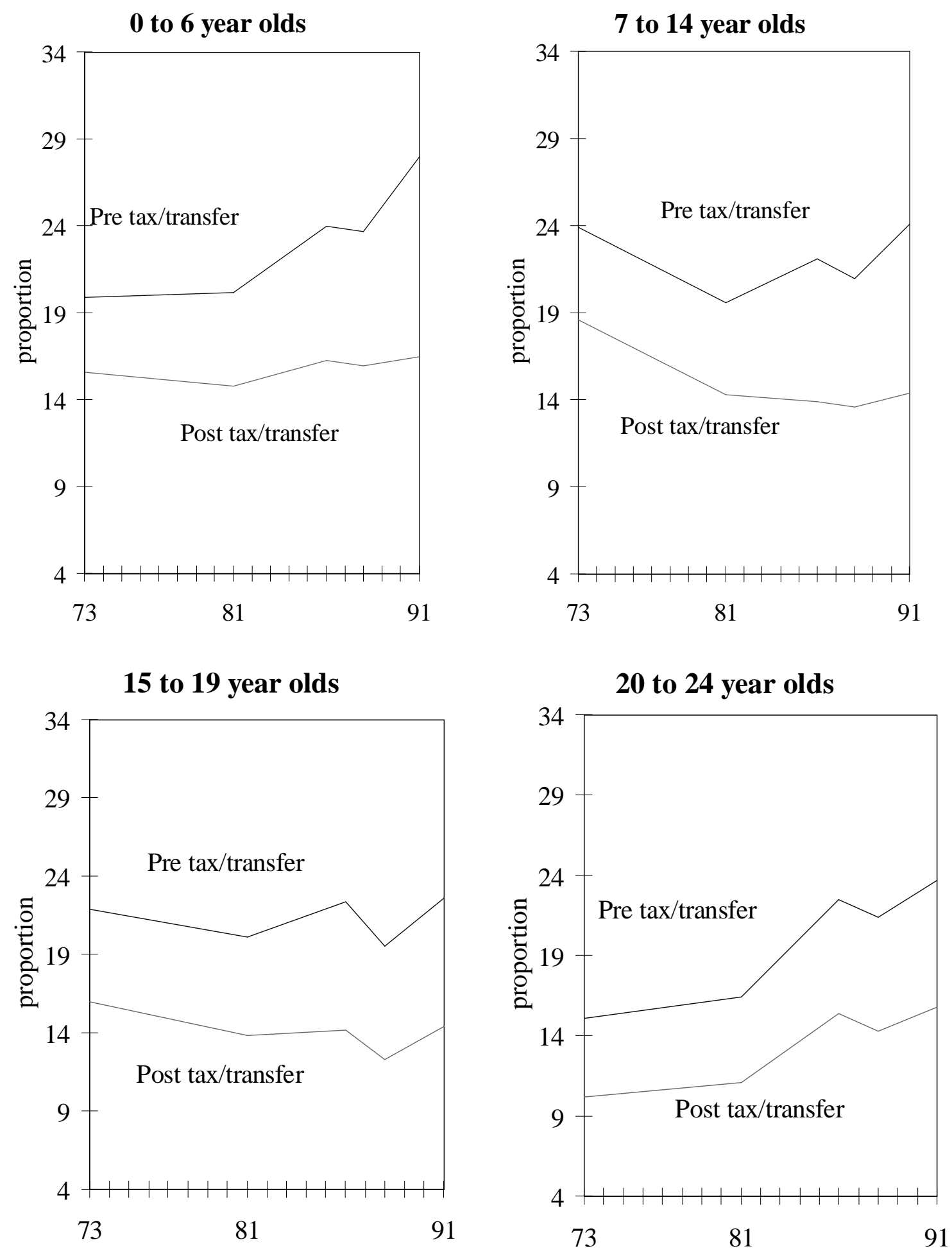
Chart 7 (Cont'd): Proportion of Individuals with Family Incomes Below 0.5 Median Income, by age
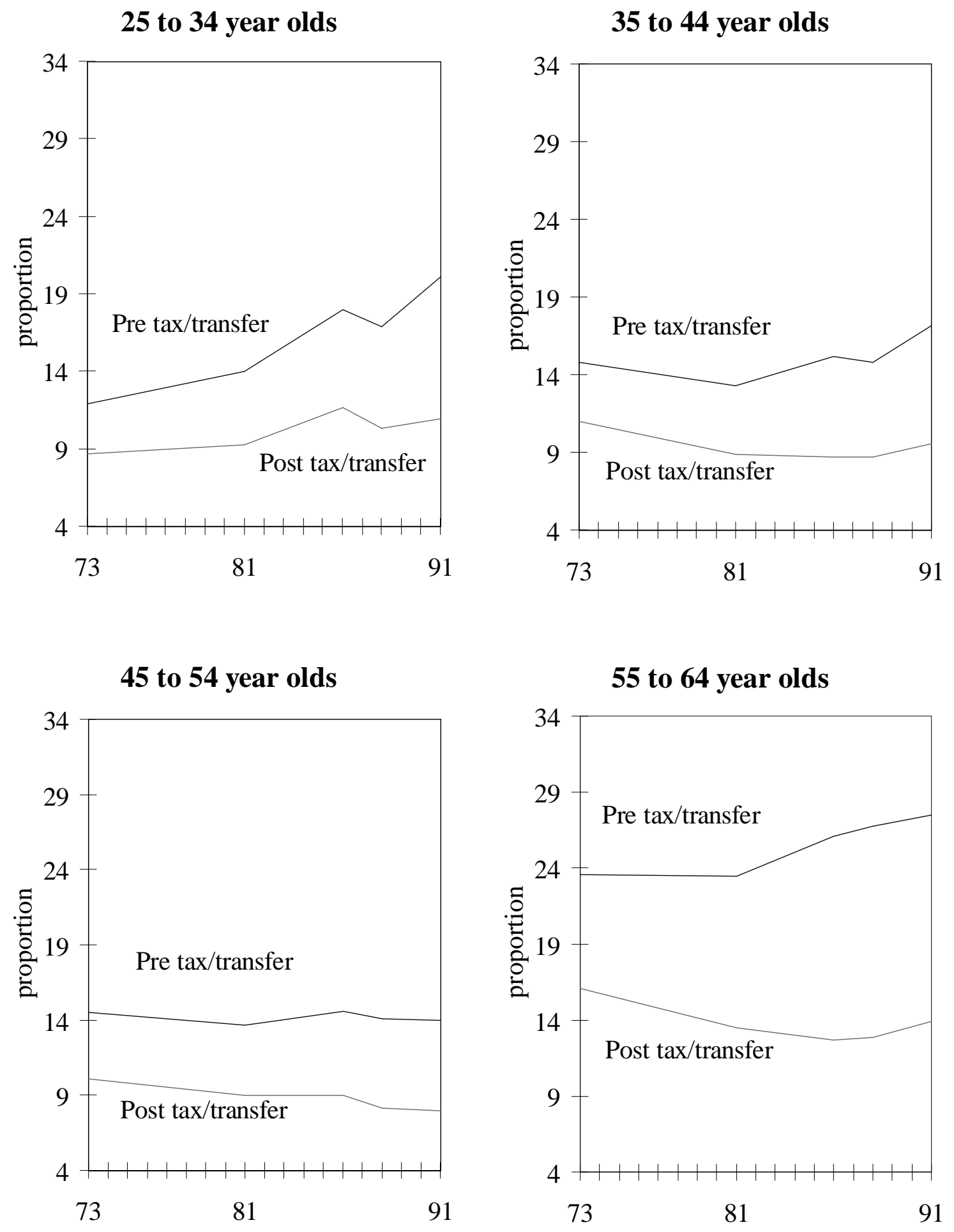
Children are poor because they live in poor families. Changes in the incidence of low income can occur because of changes in the characteristics of the households in which they reside, changes in the risk of poverty associated with these characteristics, or both. For example, the risk of low income is usually higher among children of parents with little education because of their lower earnings potential. Thus, a change in the educational composition of families with children can alter the overall incidence of low income. However, the risk of low income given a particular level of education may also change over time, as the wage gap between adults with more or less education rises or falls. This too would tend to influence the level of low income. The goal of this section is to assess the impact on low income of these two types of change. The emphasis is on the changing composition of families with children.

There is reason to believe that changing family structure (composition) has had a significant influence on low income among children. The demographic and labour market characteristics of the Canadian population has changed substantially since the 1970s. These changes are also evident in the changing characteristics of the households in which children reside (Tables 4 \& 5). Among 0-6 year olds, for example, a number of changes took place which would tend to reduce the likelihood of low income among children.

These include:

1. The proportion of children in families where the highest earner has at least some postsecondary education rose from $25 \%$ in 1973 to over $40 \%$ in 1991, increasing the earning power of these families.

2. The share of children in families with two or more adult earners rose dramatically from $38 \%$ to $62 \%$ over the period, again increasing the earning power of families.

3. The number of children per family fell (the proportion with two or less increased from $60 \%$ to $70 \%$ ), resulting in a lower risk of low income as there are fewer people to share the family resources.

4. The age at which families are having children rose (the proportion of children in families with the highest earner under age 26 fell from 18\% to 11\%), which would tend to increase the family income, as older families generally have higher earnings.

All of these changes would tend to reduce the likelihood of low income among children.

There is, of course, one quite high profile change in families that would tend to raise the incidence of low income among children; namely the increase in the proportion of children in single parent families, which rose from approximately $5 \%$ in 1973 to $11 \%$ in $1991^{10}$

10 Recall we are using economic families, which includes immediate families and other related individuals. If a single mom moves in with her parents, the child would be seen to be in a household with two or more adults (in the economic family), not one. This would not be seen as a single parent family in our work, since we are interested in the economic resources available to the child. Where single parents are defined an a "census" family basis, where only actual parents are included in the family, the share of children in single parent families is seen to be around 14\% in 1991, not $11 \%$ as indicated here. 
In light of these changes and their well known association with low income (Sharif and Phipps, 1994), our aim in this section is to estimate their effects on the prevalence of low income among children. We employ a commonly used approach of decomposing the total change in the dependent variable (the probability of a child having a family income below $50 \%$ of the median) into two components: first, that due to changes in the distribution of children among household types; and, second, that due to the changes in the relative risk of low income in households defined by a particular set of characteristic. Among other things, we show that over the 1973-91 period the actual incidence of low income among children age 0-6 changed very little. This modest change masked two much larger changes: a 4.7 percentage point increase because the likelihood of low income rose within family types (with a given set of characteristics) and a 3.8 percentage point decline because of changes in the distribution of children among family types. More simply, while on average the risk of low income among children in families with particular characteristics was rising over the period, this trend was offset by the fact more children were living in households with two earners, fewer of them had other siblings requiring support and so forth.

Martin Dooley (1993) has conducted a similar analysis using families rather than individuals as the unit of analysis and comes to somewhat different conclusions. His findings indicate that both the "within" and "between" group effects tended to reduce poverty between 1973 and 1990. These differences reflect differences in the unit of analysis (families vs individuals), the variables ("risk factors") included and methodology. ${ }^{11}$ Gottschalk and Danziger (1993) also address this issue using a regression decomposition methodology and U.S. data, and conclude that changing characteristics of women and declining numbers of children per family had a reducing effect on child poverty, while the "within" group effects and increasing numbers of single parents tended to increase poverty among white children.

\section{The Approach}

We employ logistic regression analysis, where the dependent variable takes on the value 1 if a child is in a family with income below 0.5 of the median income. Income is adult equivalent adjusted disposable (after taxes and transfers) family income. The unit of analysis is the individual, and family characteristics, including income, are associated with each individual. The sample population weights are used in the logistic regressions. Separate regressions are run for children aged 0-6 and 7-14, as the income trends and the changing demographics are somewhat different for these populations of children.

11 Our analysis differs from Dooley's in a number of ways. First, our unit of observation is the individual, not the family; we look at the AE adjusted family income of individuals, not the total disposable family income of different types of families. Second, Dooley used Statistics Canada's low-income cutoff as the indicator of low income. We use the proportion of children below one-half of the median (disposable AE adjusted) income as an indicator of low income, in part so that we can compute "low income" based on both pre and post transfer incomes. Finally, we incorporated somewhat different variables, in particular the number of earners in the family, which is excluded in his analysis. It is likely that the inclusion of this variable, and the dramatic increase in the share of children in two earner families, accounts for much of the difference in our results. 
Table 4: Distribution of Children by a Number of Demographic/ Labour Market Variables Aged 0-6 -

\section{$\begin{array}{llll}1973 & 1981 & 1988 & 1991\end{array}$}

Age of Family*

$\begin{array}{llll}\% & \% & \% & \%\end{array}$

$<26$

$17.8 \quad 17.0$

12.6

10.7

27-34

$47.2 \quad 52.8$

$35-44$

$28.3 \quad 25.9$

50.5

49.5

$45-54$

$5.7 \quad 3.3$

32.0

34.6

$55+$

1.0

1.1

3.8

3.7

$1.0 \quad 1.5$

Education of Highest Earner

Elementary

Secondary

$25.9 \quad 13.3$

13.3

7.9

6.7

$48.2 \quad 49.2$

48.4

52.0

College/Some P.S.

$16.2 \quad 22.8$

26.2

23.9

Univ Grad

$9.6 \quad 14.7$

17.5

17.4

Number of Adult Earners

0

1

4.1

4.2

5.5

8.3

57.9

43.1

31.0

29.7

$2+$

38.1

52.7

63.4

62.0

Number of Children in Family

1

2

3

$4+$

Family Type

Single Parent

Two Parent

* determined by the age of the highest earner in the family

$\begin{array}{cccc}19.7 & 24.7 & 24.7 & 24.3 \\ 40.2 & 47.3 & 48.3 & 46.3 \\ 23.4 & 20.8 & 19.5 & 21.2 \\ 16.6 & 7.3 & 7.5 & 8.3\end{array}$

$\begin{array}{cccc}5.5 & 6.4 & 9.3 & 10.7 \\ 94.5 & 93.6 & 90.7 & 89.3\end{array}$


Table 5: Distribution of Children by a Number of Demographic/ Labour Market Variables Aged 7-14

\section{$\begin{array}{llll}1973 & 1981 & 1988 & 1991\end{array}$}

Age of Family*

$\begin{array}{cccc}\% & \% & \% & \% \\ 2.9 & 2.7 & 1.6 & 1.7 \\ 15.9 & 21.9 & 21.0 & 20.9 \\ 52.8 & 54.0 & 60.5 & 58.9 \\ 24.0 & 18.2 & 14.6 & 16.5 \\ 4.5 & 3.2 & 2.3 & 2.1\end{array}$

Education of Highest Earner

Elementary

Secondary

$34.7 \quad 23.2$

12.7

9.3

College/Some P.S.

$45.2 \quad 45.8$

$45.3 \quad 53.8$

Univ Grad

$12.8 \quad 18.5$

24.2

20.4

$\begin{array}{llll}7.3 & 12.6 & 17.7 & 16.6\end{array}$

Number of Adult Earners

$\begin{array}{lcccc}0 & 4.6 & 4.3 & 5.1 & 6.1 \\ 1 & 41.4 & 31.6 & 25.5 & 25.1 \\ 2+ & 54.1 & 64.1 & 69.4 & 68.8\end{array}$

Number of Children in Family

$\begin{array}{lcccc}1 & 15.5 & 24.4 & 24.2 & 24.0 \\ 2 & 31.3 & 42.3 & 45.7 & 45.0 \\ 3 & 25.9 & 23.2 & 21.8 & 22.0 \\ 4+ & 27.3 & 10.2 & 8.4 & 9.0\end{array}$

Family Type

Single Parent

$\begin{array}{cccc}4.0 & 7.8 & 9.9 & 11.0 \\ 96.0 & 92.2 & 90.2 & 89.0\end{array}$

Two Parent

$\begin{array}{llll}96.0 & 92.2 & 90.2 & 89.0\end{array}$

*determined by the age of the highest earner in the family 
The independent variables representing the labour market and demographic composition of the families of children include:

1. five dummy variables for family age, where age is defined by the age of the highest earner ( less than 26, 27-34, 35-44, 45-54, over 55)

2. five dummy variables for family type and number of adult earners combined ((1) single parent/0 earners; (2) single parent /1 earner; (3) two-parent/ 0 earner; (4) two parent/ 1 earner; (5) two parent/ 2 or more adult earners)

3. four dummy variables for the number of children in the economic family $(1,2,3,4$ or more)

4. four dummy variables for the education level of the adult with the highest earnings (elementary, secondary, some post-secondary or college completed, university completed)

Other interaction terms were considered, particularly between the single parent ltwo parent variable and education and age, but they were found to be insignificant, and hence dropped.

In essence, the change in the low income position of children is decomposed into that due to changes in the mix of children among demographic groups over the period, and that due to changes in the probability of having a low income within specific demographic groups (i.e. controlling for demographic change).

The logistic model is written as

$Y=\frac{1}{1+e^{-\beta x}}$

where $\mathrm{Y}=1$ if a child's family income is $<0.5$ median family income, 0 otherwise

Transforming in the usual manner, the equation we estimate is

$\mathrm{L}=\beta \mathrm{X}+\mathrm{u}$

Where $L=\ln \left(\frac{P}{1-P}\right)$ is the logit, $\mathrm{P}=\operatorname{Pr}\{\mathrm{Y}=1 \mid \mathrm{X}\}, \mathrm{X}$ is a vector of independent variables, $\beta$ is the vector of associated coefficients

Using data for 1981, we obtain $\mathrm{L}_{81}=\beta_{81} \mathrm{X}_{81}+\mathrm{u}$, and we then compute $\bar{P}_{81}$, the overall mean probability of a child having less than 0.5 medium family income in 1981 . This calculation is done 
in the manner described in the footnote below to ensure it matches the overall mean probability (i.e. proportion) observed in the raw data. ${ }^{12}$

To decompose the total change in P between, say 1981 and 1988, into that due to changes in family composition (i.e. changes in the independent variables) and changes in the risk of being in low income given a particular set of characteristics (i.e. changes in the coefficients), we:

1. Alter the composition of families (independent variables), keeping the value of the coefficients fixed at the 1981 values.

Thus $\mathrm{L}^{*}=\beta_{81} \mathrm{X}_{88}$. We compute $\mathrm{L}^{*}$, and calculate $\bar{P} *$ as described in the footnote.

Then $\bar{P}^{*}-\bar{P}_{81}=$ the change in $\bar{P}$ between 81 and 88 due to the change in the composition of families with children

2. We then alter the coefficients from their 1981 to 1988 values, thus;

$$
\begin{aligned}
& \mathrm{L}_{88}=\beta_{88} \mathrm{X}_{88}, \text { and compute } \bar{P}_{88} . \\
& \text { Then } \bar{P}_{88}-\bar{P}^{*}= \text { change in } \mathrm{P} \text { due to change in the risk of being in low income } \\
& \text { given a particular set of family characteristics (i.e. to change } \\
& \text { in coefficients) }
\end{aligned}
$$

Whether the coefficients or the values of the variables are altered first does matter; it is done both ways and the average value of the two results used. Also, the usual caveat associated with the interpretation of such results applies here. There are no explicit behavioural links between the two basic factors (demographic change and the income position of children within demographic groups) in the model, although in reality there almost certainly are. To some extent, changes in the economic position of families and changes in family composition are jointly determined. Ideally one would like to estimate the effect of exogenous changes in demography and labour market circumstance on the likelihood of low income, but there is some endogeneity in the model. If economic conditions of, say, young families with low levels of education deteriorate, this may

12 To calculate the estimated mean probability of a child having a family income below one half the median, one could simply estimate the probability at the mean values of the variables. However, since we are using a nonlinear function, this typically does not match sample mean derived from the raw data. Thus, we estimate the mean probability by estimating the probability of each child in the sample having a family income below one half the median based on the regression equation and then averaging these probabilities across all individuals in the sample (using the sample weights). In this way the probability estimated using the regression equation matches the sample mean from the raw data.

Thus, $\bar{P}_{81}=\frac{\sum_{i=1}^{n} w_{i} \hat{P_{i, 81}}}{\sum_{i=1}^{n} w_{i}}$

where $\mathrm{w}_{\mathrm{i}}$ is the sample weight associated with individual $\mathrm{i}, \mathrm{n}$ is the number of observations, and where $\hat{P}_{i, 81}$ is the estimated probability for individual $\mathrm{i}$ in year 1981, which is computed as follows:

$\hat{P}_{i, 81}=\frac{1}{1+e^{-B_{81} X_{i, 81}}}$ 
well influence their probability of having children, and hence the demographic composition of children. Also, declining labour market earnings of young individuals may have prompted many second earners in young families to enter the labour market. Such relationships are not addressed here. Hence, the results provide a decomposition of history in an accounting sense. They estimate the direct, but not indirect, influence of these factors on low income among children during the period. We believe that such estimates make a contribution to understanding changes in low income that took place over the past two decades. This approach and its results are of interest to policy-makers who are concerned about the impact of economic and demographic changes, regardless of their source.

\section{The Results}

The logistic regression results for 1973, 1981, 1988, and 1991, based on disposable (post tax/transfer) income, for both 0-6 and 7-14 year old children are shown in Appendix Table 2. Rather than referring directly to the coefficients, which are difficult to interpret in an intuitive manner, the actual probabilities ${ }^{13}$ and relative probabilities ${ }^{14}$ are also shown in the appendix for the years 1973 , 1981, 1988 and 1991. There are a number of reasons to be interested in these probabilities. They demonstrate both the enormous difference in the risk of low income among children who are in different types of families, and how this gap in the risk of poverty has narrowed among some family types over the past twenty years. But as this story is not central to our analysis, we have relegated it to Appendix B, where interested readers can pursue it.

\section{Decomposition Results For 1973 to 1991}

Over the 1973-91 period, there was relatively little change in the actual incidence of low income, as noted earlier. For example, among children aged 0-6, the actual proportion with low incomes rose slightly...0.9\%. But this small change masked two larger changes...a 4.7 percentage point increase because the likelihood of being in a low income group rose within the family types defined by the variables in the equation, and a 3.8 percentage point decline because the mix of children among the family types changed as described earlier between 1973 and 1991. More children were in households with two earners, they had fewer siblings, and so forth. Put another way, although the aggregate proportion of children in low income families changed little over the period, when the demographic mix of children is held constant, this rate is seen to rise. And this rise occurs after the increasing role of the transfer system, discussed earlier, is accounted for, since we are using after tax/transfer income in this analysis. As noted earlier, these two effects are not independent, and it is difficult to disentangle them. But demographic/labour changes in families have tended to put significant downward pressure on low income among children.

At first glance this finding seems contrary to popularly held beliefs, as it is well known that the proportion of children in single parent families has been increasing, and this would tend to increase

\footnotetext{
13 Evaluated at the mean values of the variables.

14 Relative to the reference group with the lowest probability.
} 
the incidence of low income. But other changes in family structure have been taking place that tend to swamp the effect of rising numbers of single parent families. They include in particular the trend towards more dual earner families and the decreasing number of children per family. While there has been an increase in the number of single parent families, which would have placed upward pressure on child poverty, this effect is small relative to other changes in the household characteristics of children.

The results for children aged 7-14 are more pronounced (Table 6). While the actual rate fell by 4.2 percentage points, this was associated largely with changing demographics, which put downward pressure to the tune of 7.0 percentage points on the share of children in low income. In contrast, the risk of low income within family types rose by 2.8 percentage points for this group.

Table 6: Decomposition of the Change in Probability of Being in a Low Income Family, Children Aged 0-6 and 7-14, 1973-91 and 1981-88, Disposable Income

\section{Probability of being in low income family**}

\author{
Change in Change* due to \\ probability \\ change in B \\ coefficients
}

\author{
Change* due to \\ change in value \\ of variables \\ (composition)
}

\begin{tabular}{|c|c|c|c|c|c|}
\hline $\begin{array}{l}\text { Children } \\
\text { aged: }\end{array}$ & 1973 & 1991 & & & \\
\hline 0 - 6 & .156 & .165 & +.009 & +.047 & -.038 \\
\hline \multirow[t]{2}{*}{$7-14$} & .186 & .144 & -.042 & +.028 & -.070 \\
\hline & 1981 & 1988 & & & \\
\hline $0-6$ & .148 & .160 & +.012 & +.024 & -.012 \\
\hline $7-14$ & .143 & .136 & -.007 & +.015 & -.021 \\
\hline
\end{tabular}

* the order in which the B's and X are altered from 1973 to 1991 matters. These values are the average of the two ordering, where first the B's are altered, followed by the X's, and then the opposite.

** Below 0.5 median income 


\section{Results for the 1981- 1988 Period}

The 1981-88 period is of particular interest for several reasons. First, much of the change in "demographics" occurred in the 1970s. Changing demographics may be less correlated with changes in the prevalence of low income in the 1980s. In particular, the major changes in the educational attainment, number of children and number of adult earners in families with children took place before 1981 (Table 4 and 5). These trends continued into the 1980s but at a decelerated pace. Conversely, changes in the economic fortunes of young adults -- the decline in real and relative earnings-- were mainly a product of the 1980s (Morissette, Myles and Picot, 1994). Finally, changes that occurred between 1988 and 1991 are affected by the recession that began in 1990, and hence confound any underlying secular trends with fluctuations in the business cycle. Focusing on 1981 and 1988, roughly business cycle peaks, allows us to focus on longer term trends which are not significantly influenced by business cycle variation.

Among 0-6 year olds, the actual proportion below one-half of the median income rose between 1981 and 1988 , from 14.8 to 16.0 percent, a change of 1.2. As before, this small change was the result of two contrary motions. Changes in demography tended to reduce this by 1.2 while changes in the coefficients are associated with a rise of 2.4 percentage points. Similar trends are evident for the 7-14 age group; the decline of 0.7 percentage points was a combination of a 2.1 point decline due to demographic changes, and a 1.5 point increase due to changes in the likelihood of low income within groups. Thus, both factors played about an equal role over this period. Demographic effects were considerably less than during the 1973 to 1981 period, but still significant. During the 1980s the changing demographic/labour market participation pattern of families tended to reduce the incidence of low income among children.

\section{Summary and Discussion}

Rising inequality in labour market earnings has been among the most significant economic developments of the past two decades. Despite dramatic changes in the distribution of labour market incomes, however, the distribution of total family income has remained remarkably stable (Love and Poulin, 1992; Statistics Canada, 1993). Similarly, while young adults have borne the brunt of declining earnings at the bottom of the labour market, the prevalence of low incomes among young parents and their children has continued to follow the ups and downs of the business cycle rather than the long term secular trend towards lower earnings in this age group.

Our analysis has emphasized two reasons for this stability. As in previous studies (Dooley, 1993; Hanratty and Blank, 1992), we have documented the increasing importance of social transfers in stabilizing the economic conditions of young families and their children. Based on market income alone, children and their parents were at a substantially greater risk of being in a low income family in the late 1980s and early 1990s than in 1973 or 1981.

But transfers were not the whole story. The kinds of families in which children live today are very different from those of their predecessors of one or two decades ago. Their parents are having fewer children, and are having them at a later age; parents are better educated, are collectively working longer hours because mothers are more likely to be in the labour force. Rather than losing the work 
ethic, young Canadian families are working harder to maintain their standard of living. These demographic/labour supply changes are to a considerable degree responsible for the apparent stability observed in the median incomes and rates of low income among young families. Holding demographic change constant, the risk of low income between 1973 and 1991 rose by 4.7 and 2.8 percentage points among 0-6 and 7-14 year old children respectively. And since this is based an post tax/transfer income, the effect of rising transfers has already been accounted for in this result. Changing demographics put substantial downward pressure on the aggregate rate of low income among children. While much has been made of the rise of single-parenthood and its consequences for child poverty, other behavioural changes among young adults more than offset this development.

To draw policy conclusions from these results, however, requires assumptions regarding causation. As we have emphasized, our analysis is a descriptive accounting of history, not behavioural-causal. Most notably, we do not directly account for possible work disincentive effects. There is a point often advanced by critics of social spending such as Charles Murray (1984) that easier access to social transfers is a major cause of low earnings and child poverty. By providing an alternative to the labour market, they argue, the welfare state creates incentives for individuals and families to reduce labour force participation and encourages dependency on the state. The relevant counterfactual then is not the actual historical pattern of low income under market earnings alone, which we present, but what would have happened in the absence of social transfers.

But the central issue is not whether work disincentives exist, they almost certainly do, but whether their magnitude could be such as to explain the declining market earnings and potentially rising low income observed in this work. We argue that the size of the disincentive effects are too small to explain most of the story we present here. There are a number of reasons we believe this. Hum and Simpson's (1991) review of labour supply elasticities indicates that the labour supply responses to changes in the tax-transfer system are quite small. Furthermore, there is a possibility that the very large changes in the inequality of labour market earnings in the 1980s could be explained by increasing disincentives in the transfer system. This was addressed in the US and largely rejected (Moffit, 1990). Furthermore, the decline in youth earnings, which is a large part of the story presented here, has been observed in most western countries (Davis, 1992) which have dramatically different social security systems with vastly different incentive effects. And there is the experience of the U.S. during the 1980s. They experienced rising earnings inequality and declining youth wages as we did here in Canada, but their transfer system was being retrended during this period. Hence, work disincentive effects would have been in the decline, not increasing, yet earnings fell none-the-less among the lower paid and younger workers. The most recent comparative evidence on the relation between social protection and labour market flexibility (Blank, 1994) concludes that if there is a trade-off, its magnitude is small. Another reason to believe that rising disincentive effects cannot account for the majority of the earning change observed in Canada is that for many of the programs, such as UI, the program was changed to make it less generous, not more, to individuals through the 1980s (Sargeant, 1995). Thus, one would expect disincentive effects to be reduced, not increased, at least in the UI system. Work disincentives associated with the social assistance (welfare) system could have been increasing through the 1980s in Canada as rules in some provinces were liberalized, however.

After almost a decade of research, explanations for the growth in inequality and declining earnings at the bottom of the labour market are not focusing on the effects of transfer systems, but have turned to the demand side of the labour market and emphasize changing trade patterns and new technologies. 
Our results indicate that in Canada both households and governments have responded to the labour market restructuring that has taken place as a result. During the 1980s, social transfers to non-elderly households increased from 5.5 to 7.6 percent of GDP (OECD, 1994). Young Canadian families are working more hours, having fewer children and bearing them at older ages than in the past. Changing labour market conditions have been met with adjustments in family structures rising transfer payments. The net effect has been stable "low income" rates among children. It remains to be seen whether these offsetting adjustments will prevail in the labour markets of the late 1990s. 
Appendix Table 1: Changing Economic Status of Canadians by Age Group; Adult Equivalent Adjusted Family Income of Individuals

Age Group Characteristics

0 to 6

Number of Persons ( ' 000)

Pre Tax Pre Transfer Income

Median Income (1991 \$000's)

Index $($ Base Year $=1973)$

Relative Median Income

\% Below 0.5 Median Income

Post Tax Post Transfer Income

Median Income (1991 \$000's)

Index $($ Base Year $=1973)$

Relative Median Income

$\%$ Below 0.5 Median Income

7 to $14 \quad$ Number of Persons ( ' 000)

Pre Tax Pre Transfer Income

Median Income (1991 \$000's)

Index $($ Base Year $=1973)$

Relative Median Income

\% Below 0.5 Median Income

Post Tax Post Transfer Income

Median Income (1991 \$000's)

Index $($ Base Year $=1973)$

Relative Median Income

$\%$ Below 0.5 Median Income

15 to 19 Number of Persons ( ' 000)

Pre Tax Pre Transfer Income

Median Income (1991 \$000's)

Index $($ Base Year $=1973)$

Relative Median Income

$\%$ Below 0.5 Median Income

Post Tax Post Transfer Income

Median Income (1991 \$000’s)

Index $($ Base Year $=1973)$

Relative Median Income

$\%$ Below 0.5 Median Income

$\begin{array}{rrrrr}\mathbf{1 9 7 3} & \mathbf{1 9 8 1} & \mathbf{1 9 8 6} & \mathbf{1 9 8 8} & \mathbf{1 9 9 1} \\ & & & & \\ 2,452 & 2,442 & 2,497 & 2,519 & 2,643 \\ & & & & \\ 16.9 & 20.2 & 20.1 & 20.8 & 19.5 \\ 100 & 120 & 119 & 123 & 115 \\ 0.93 & 0.90 & 0.90 & 0.89 & 0.88 \\ 19.9 & 20.2 & 24.0 & 23.7 & 28.0 \\ & & & & \\ & & & & \\ 15.4 & 18.3 & 18.2 & 18.7 & 18.0 \\ 100 & 119 & 118 & 121 & 117 \\ 0.91 & 0.88 & 0.88 & 0.87 & 0.87 \\ 15.6 & 14.8 & 16.3 & 16.0 & 16.5\end{array}$

$\begin{array}{lllll}3,448 & 2,865 & 2,772 & 2,820 & 2,909\end{array}$

$\begin{array}{rrrrr}15.8 & 20.6 & 21.5 & 22.2 & 21.0 \\ 100 & 130 & 136 & 141 & 133 \\ 0.87 & 0.92 & 0.96 & 0.95 & 0.95 \\ 23.9 & 19.6 & 22.1 & 21.0 & 24.1\end{array}$

$\begin{array}{lllll}14.6 & 18.9 & 19.1 & 19.6 & 18.9\end{array}$

$\begin{array}{lllll}100 & 130 & 131 & 135 & 130\end{array}$

$\begin{array}{lllll}0.86 & 0.91 & 0.92 & 0.92 & 0.92\end{array}$

$\begin{array}{lllll}18.6 & 14.3 & 13.9 & 13.6 & 14.4\end{array}$

$\begin{array}{lllll}1,969 & 2,179 & 1,857 & 1,822 & 1,788\end{array}$

$\begin{array}{lllll}17.1 & 22.2 & 22.8 & 24.3 & 22.2\end{array}$

$\begin{array}{lllll}100 & 129 & 133 & 142 & 130\end{array}$

$\begin{array}{lllll}0.94 & 0.99 & 1.02 & 1.04 & 1.01\end{array}$

$\begin{array}{lllll}21.9 & 20.1 & 22.4 & 19.5 & 22.6\end{array}$

$\begin{array}{lllll}16.2 & 20.4 & 20.8 & 21.4 & 20.2\end{array}$

$\begin{array}{lllll}100 & 126 & 128 & 132 & 124\end{array}$

$\begin{array}{lllll}0.96 & 0.98 & 1.00 & 1.00 & 0.98\end{array}$

$\begin{array}{lllll}16.0 & 13.8 & 14.2 & 12.3 & 14.4\end{array}$ 
Appendix Table 1 (Cont'd): Changing Economic Status of Canadians by Age Group; Adult Equivalent Adjusted Family Income of Individuals

\begin{tabular}{|c|c|c|c|c|c|c|}
\hline Age Group & Characteristics & 1973 & 1981 & 1986 & 1988 & 1991 \\
\hline \multirow[t]{11}{*}{20 to 24} & Number of Persons ( ' 000) & 1,809 & 2,287 & 2,135 & 1,982 & 1,913 \\
\hline & Pre Tax Pre Transfer Income & & & & & \\
\hline & Median Income (1991 \$000’s) & 20.5 & 24.9 & 22.6 & 24.6 & 22.0 \\
\hline & Index $($ Base Year $=1973)$ & 100 & 121 & 110 & 120 & 107 \\
\hline & Relative Median Income & 1.12 & 1.11 & 1.00 & 1.05 & 1.00 \\
\hline & $\%$ Below 0.5 Median Income & 15.1 & 16.4 & 22.5 & 21.4 & 23.7 \\
\hline & Post Tax Post Transfer Income & & & & & \\
\hline & Median Income (1991 \$000’s) & 18.9 & 22.6 & 20.6 & 22.1 & 20.6 \\
\hline & Index $($ Base Year = 1973 $)$ & 100 & 120 & 109 & 117 & 109 \\
\hline & Relative Median Income & 1.11 & 1.09 & 1.00 & 1.04 & 1.00 \\
\hline & $\%$ Below 0.5 Median Income & 10.2 & 11.1 & 15.4 & 14.3 & 15.8 \\
\hline \multirow[t]{11}{*}{25 to 34} & Number of Persons ( ' 000) & 3,053 & 4,169 & 4,478 & 4,581 & 4,624 \\
\hline & Pre Tax Pre Transfer Income & & & & & \\
\hline & Median Income (1991 \$000’s) & 21.7 & 25.1 & 24.6 & 25.6 & 23.6 \\
\hline & Index $($ Base Year = 1973 $)$ & 100 & 115 & 113 & 118 & 109 \\
\hline & Relative Median Income & 1.19 & 1.12 & 1.09 & 1.09 & 1.07 \\
\hline & $\%$ Below 0.5 Median Income & 11.9 & 14.0 & 18.0 & 16.9 & 20.1 \\
\hline & Post Tax Post Transfer Income & & & & & \\
\hline & Median Income (1991 \$000’s) & 19.2 & 22.2 & 21.7 & 22.2 & 21.1 \\
\hline & Index $($ Base Year $=1973)$ & 100 & 116 & 113 & 116 & 110 \\
\hline & Relative Median Income & 1.13 & 1.07 & 1.05 & 1.04 & 1.03 \\
\hline & $\%$ Below 0.5 Median Income & 8.7 & 9.3 & 11.7 & 10.3 & 11.0 \\
\hline \multirow[t]{11}{*}{35 to 44} & Number of Persons ( ' 000) & 2,441 & 3,034 & 3,671 & 3,919 & 4,294 \\
\hline & Pre Tax Pre Transfer Income & & & & & \\
\hline & Median Income (1991 \$000’s) & 19.6 & 25.8 & 26.2 & 27.2 & 25.8 \\
\hline & Index $($ Base Year = 1973) & 100 & 132 & 134 & 139 & 132 \\
\hline & Relative Median Income & 1.07 & 1.15 & 1.17 & 1.16 & 1.17 \\
\hline & $\%$ Below 0.5 Median Income & 14.8 & 13.3 & 15.2 & 14.8 & 17.2 \\
\hline & Post Tax Post Transfer Income & & & & & \\
\hline & Median Income (1991 \$000’s) & 17.6 & 22.7 & 22.5 & 23.0 & 22.3 \\
\hline & Index $($ Base Year = 1973) & 100 & 129 & 128 & 131 & 127 \\
\hline & Relative Median Income & 1.04 & 1.09 & 1.08 & 1.08 & 1.08 \\
\hline & $\%$ Below 0.5 Median Income & 11.0 & 8.9 & 8.7 & 8.7 & 9.6 \\
\hline
\end{tabular}


Appendix Table 1 (Cont'd): Changing Economic Status of Canadians by Age Group; Adult Equivalent Adjusted Family Income of Individuals

Age Group Characteristics

45 to $54 \quad$ Number of Persons ( $\left.{ }^{\prime} 000\right)$

Pre Tax Pre Transfer Income

Median Income (1991 \$000's)

Index $($ Base Year $=1973)$

Relative Median Income

$\%$ Below 0.5 Median Income

Post Tax Post Transfer Income

Median Income (1991 \$000's)

Index (Base Year = 1973)

Relative Median Income

$\%$ Below 0.5 Median Income

55 to $64 \quad$ Number of Persons ( ' 000)

Pre Tax Pre Transfer Income

Median Income (1991 \$000's)

Index $($ Base Year = 1973)

Relative Median Income

$\%$ Below 0.5 Median Income

Post Tax Post Transfer Income

Median Income (1991 \$000's)

Index $($ Base Year $=1973)$

Relative Median Income

$\%$ Below 0.5 Median Income

65 to $74 \quad$ Number of Persons ( ' 000)

Pre Tax Pre Transfer Income

Median Income (1991 \$000's)

Index $($ Base Year $=1973)$

Relative Median Income

$\%$ Below 0.5 Median Income

Post Tax Post Transfer Income

Median Income (1991 \$000's)

Index $($ Base Year $=1973)$

Relative Median Income

\% Below 0.5 Median Income
1973

1981

1986

1988

1991

2,454

2,536

2,678

3,027

22

100

27.7

124

28.5

127

1.27

14.6

30.1

134

1.29

14.1

29.7

1.23

13.7

20.1

100

24.8

24.6

26.0

129

1.21

1.19

1.19

10.1

9.0

9.0

8.2

133

1.35

14.0

1,710

2,161

2,303

2,318

2,347

20.1

20.1
100

24.0

23.4

116

23.5

117

1.00

1.04

26.8

25.6

127

1.24

8.0

1.11
23.6

1.07
23.5

26.1

22.4

111

1.01

27.5

19.1

100

22.7

22.5

22.6

21.9

1.13

119

118

118

115

16.1

1.09

1.09

1.06

1.06

13.5

12.7

12.9

13.9

1,109

1,438

1,607

1,726

1,837
6.7

100

$$
8.7
$$

129

0.39

56.4

56.2

13.0

100

16.2

125

0.78

0.77

16.6
7.7

115

0.34

60.1

16.8

129

0.81

8.5
8.2

122

0.35

59.7

8.8

131

0.40

56.3

23.1
17.4

134

0.81

9.3
18.1

0.88

4.7 
Appendix Table 1 (Cont'd): Changing Economic Status of Canadians by Age Group; Adult Equivalent Adjusted Family Income of Individuals

Age Group Characteristics

Total Age Number of Persons (' 000)

Pre Tax Pre Transfer Income

Median Income (1991 \$000’s)

Index $($ Base Year $=1973)$

Relative Median Income

$\%$ Below 0.5 Median Income

Post Tax Post Transfer Income

Median Income (1991 \$000's)

Index $($ Base Year $=1973)$

Relative Median Income

$\%$ Below 0.5 Median Income $\begin{array}{lllll}1973 & 1981 & 1986 & 1988 & 1991\end{array}$

$\begin{array}{lllll}20,805 & 23,814 & 24,807 & 25,347 & 26,495\end{array}$

$\begin{array}{lllll}18.2 & 22.4 & 22.4 & 23.4 & 22.1\end{array}$

$\begin{array}{lllll}100 & 123 & 123 & 129 & 121\end{array}$

$\begin{array}{lllll}1.00 & 1.00 & 1.00 & 1.00 & 1.00\end{array}$

$\begin{array}{lllll}21.5 & 21.1 & 24.4 & 23.8 & 25.6\end{array}$

$\begin{array}{lllll}16.9 & 20.8 & 20.7 & 21.4 & 20.6\end{array}$

$\begin{array}{lllll}100 & 123 & 122 & 126 & 122\end{array}$

$\begin{array}{lllll}1.00 & 1.00 & 1.00 & 1.00 & 1.00\end{array}$

$\begin{array}{lllll}14.3 & 12.3 & 12.1 & 11.5 & 11.5\end{array}$ 
Appendix Table 2: Logistic Regression Results of the Probability of a Child Being in a Family with an Income Less than 0.5 Median Disposable Income

\section{Aged 0 - 6}

\begin{tabular}{|c|c|c|c|c|c|c|c|c|}
\hline \multirow[b]{2}{*}{ intercept } & 1973 & $\mathbf{t}$ & 1981 & $\mathbf{t}$ & 1988 & $\mathbf{t}$ & $\begin{array}{c}1991 \\
\text { coefficient }\end{array}$ & $\mathbf{t}$ \\
\hline & -2.438 & -19.97 & -1.469 & -14.92 & -1.008 & -8.93 & -0.947 & -8.91 \\
\hline \multicolumn{9}{|l|}{ Education } \\
\hline $\begin{array}{l}\text { elementary } \\
\text { secondary }\end{array}$ & 0.832 & 11.45 & 1.093 & 13.54 & 0.765 & 6.87 & 0.554 & 5.12 \\
\hline coll/some univ & -0.623 & -5.13 & -0.642 & -6.80 & -0.422 & -4.86 & -0.577 & -6.91 \\
\hline univ degree & -1.625 & -7.29 & -0.732 & -5.97 & -0.817 & -6.60 & -0.829 & -7.53 \\
\hline $\begin{array}{l}\text { Age of Family } \\
<=26\end{array}$ & & & & & & & & \\
\hline $27-34$ & -0.700 & -7.14 & -0.722 & -8.40 & -1.097 & -11.40 & -0.604 & -6.35 \\
\hline $35-44$ & -0.659 & -6.14 & -0.704 & -7.02 & -1.717 & -15.26 & -0.886 & -8.36 \\
\hline $45-54$ & $-0.149 *$ & -1.03 & $-0.221 *$ & -1.34 & -1.237 & -6.24 & -0.538 & -2.78 \\
\hline $55+$ & $0.073 *$ & 0.25 & $-0.187 *$ & -0.67 & -2.371 & -5.92 & -2.181 & -6.27 \\
\hline \multicolumn{9}{|c|}{ Number of Earners/Family Type } \\
\hline lone par/ no earn & 4.852 & 18.18 & 4.397 & 17.43 & 4.108 & 18.31 & 2.478 & 21.60 \\
\hline lone par/ 1 earn & 2.120 & 15.02 & 1.363 & 11.71 & 1.633 & 14.78 & 1.482 & 14.25 \\
\hline $\begin{array}{l}\text { two par/ no earn } \\
\text { two par/ } 1 \text { earn }\end{array}$ & 3.638 & 14.04 & 3.809 & 13.24 & 3.870 & 13.08 & 2.524 & 17.41 \\
\hline two par/ 2+ earn & -0.791 & -9.91 & -1.214 & -16.87 & -1.362 & -17.54 & -1.409 & -18.70 \\
\hline \multicolumn{9}{|c|}{ Number of Children } \\
\hline 1 & & & & & & & & \\
\hline 2 & 0.501 & 4.18 & $0.141 *$ & 1.55 & 0.425 & 4.23 & $0.015 *$ & 0.18 \\
\hline 3 & 1.075 & 8.40 & 0.713 & 7.14 & 1.307 & 11.62 & 0.533 & 5.54 \\
\hline 4 or more & 2.168 & 16.84 & 1.302 & 10.84 & 2.001 & 14.93 & 1.156 & 9.77 \\
\hline Sample Size & 10078 & & 11704 & & 10559 & & 11310 & \\
\hline Model & & & & & & & & \\
\hline Chi Square & 2577.63 & & 2868.48 & & 3522.35 & & 3218.81 & \\
\hline
\end{tabular}

* - not significant 
Appendix Table 2 (cont'd): Logistic Regression Results of the Probability of a Child Being in a Family with an Income Less than 0.5 Median Disposable Income

\section{Aged 7 - 14}

\begin{tabular}{|c|c|c|c|c|c|c|c|c|}
\hline \multirow[b]{2}{*}{ intercept } & 1973 & $\mathbf{t}$ & \multicolumn{2}{|l|}{1981} & 1988 & $\mathbf{t}$ & $\begin{array}{c}1991 \\
\text { coefficient }\end{array}$ & $\mathbf{t}$ \\
\hline & -1.909 & -11.68 & -1.034 & -6.34 & -0.703 & -3.30 & -0.458 & -2.14 \\
\hline \multicolumn{9}{|l|}{$\underline{\text { Education }}$} \\
\hline $\begin{array}{l}\text { elementary } \\
\text { secondary }\end{array}$ & 0.854 & 15.57 & 0.872 & 12.93 & 0.726 & 8.18 & 0.513 & 5.58 \\
\hline coll/some univ & -0.658 & -6.23 & -0.773 & -7.84 & -0.559 & -6.34 & -0.674 & -7.61 \\
\hline univ degree & -2.575 & -9.57 & -1.247 & -8.62 & -1.327 & -10.06 & -1.027 & -8.94 \\
\hline $\begin{array}{l}\text { Age of Family } \\
<=26\end{array}$ & & & & & & & & \\
\hline $27-34$ & -0.841 & -5.49 & -0.940 & -6.13 & -1.071 & -5.23 & -1.100 & -5.30 \\
\hline $35-44$ & -0.679 & -4.80 & -1.253 & -8.52 & -1.452 & -7.24 & -1.177 & -5.81 \\
\hline $45-54$ & -0.397 & -2.74 & -0.878 & -5.61 & -1.157 & -5.42 & -1.220 & -5.65 \\
\hline $55+$ & $0.014 *$ & 0.08 & -0.543 & -2.66 & -1.226 & -4.45 & -0.693 & -2.59 \\
\hline \multicolumn{9}{|c|}{ Number of Earners/Family Type } \\
\hline lone par/ no earn & 3.890 & 15.78 & 3.967 & 18.35 & 3.951 & 18.81 & 2.740 & 20.38 \\
\hline lone par/ 1 earn & 0.989 & 7.24 & 0.857 & 8.37 & 0.844 & 7.90 & 0.421 & 4.12 \\
\hline $\begin{array}{l}\text { two par/ no earn } \\
\text { two par/ } 1 \text { earn }\end{array}$ & 3.593 & 19.25 & 3.667 & 16.90 & 3.360 & 17.83 & 2.496 & 15.22 \\
\hline two par/ 2+ earn & -0.929 & -16.89 & -1.361 & -20.53 & -1.179 & -15.36 & -1.332 & -18.60 \\
\hline \multicolumn{9}{|c|}{ Number of Children } \\
\hline 1 & & & & & & & & \\
\hline 2 & 0.267 & 2.58 & 0.294 & 3.26 & 0.217 & 2.27 & $0.109 *$ & 1.26 \\
\hline 3 & 0.812 & 7.89 & 0.821 & 8.66 & 0.807 & 7.62 & 0.554 & 5.83 \\
\hline 4 or more & 1.841 & 18.72 & 1.436 & 13.57 & 1.665 & 13.97 & 1.338 & 12.32 \\
\hline Sample Size & 14175 & & 13734 & & 11821 & & 12450 & \\
\hline \multicolumn{9}{|l|}{ Model } \\
\hline Chi Square & 3696.33 & & 3446.87 & & 3026.36 & & 2894.87 & \\
\hline
\end{tabular}

* - not significant 


\section{Appendix B: The Probability of a Child Being in a Low Income Family in 1973, 1981, 1988,} and 1991

For ease of interpretation, the actual probabilities of a child being in low income, given the characteristics of the family, are computed below. For any given variable (e.g. education), the change in the probabilities across different levels of education are computed at the mean value of the other variable in the equation. Relative probabilities (i.e. relative to some reference group) are also shown, and perhaps more interestingly, changes in these relative probabilities through time are shown.

We are interested in these probabilities for two reasons. First, they present an informative story regarding the association between being in a particular type of family and the risk of low income. They also indicate how this association has changed through time. Secondly, the often dramatic change in the demographic mix of families noted in the main text will influence the rate of low income only if there is significant variation in this rate among demographic groups. It is clear that there is.

- For example, in 1991 a child in a family where the highest earner had an elementary education was 3.4 to 4.0 times more likely to have a low family income than one in a university graduate-headed family, controlling for the other variables (Appendix Table 3).

- Children in single earner (two parent) families were 3.5 times as likely to have a low income as their two earner counterparts (controlling for other variables).

- The probability of low income was from 1.4 to 2.8 times higher in single parent one earner families than the two parent one earner family.

- In 1991, children in families with 4 or more children were 2.4 to 3.1 times more likely to have a low family income than those with a single child (controlling for other variables).

The magnitudes of the differences are very large. Hence, any change in the demographic composition among these groups could have a dramatic effect on the overall proportion of children with low income. 


\section{Appendix Table 3: Relative Probabilities of a Child Being in a Family with a Disposable Income Less than 0.5 Median Disposable Income: Estimated from a Logistic Regression Model \\ Children Aged 0 - 6 years}

\begin{tabular}{|c|c|c|c|c|c|c|c|c|}
\hline \multirow[b]{2}{*}{ Education } & $\begin{array}{c}\mathbf{1 9 7 3} \\
\text { probability } \\
(1)\end{array}$ & $\begin{array}{c}\text { relative } \\
\text { probability } \\
\text { (2) }\end{array}$ & $\begin{array}{c}\mathbf{1 9 8 1} \\
\text { probability } \\
(1)\end{array}$ & $\begin{array}{c}\text { relative } \\
\text { probability } \\
(2)\end{array}$ & $\begin{array}{c}\mathbf{1 9 8 8} \\
\text { probability } \\
\text { (1) }\end{array}$ & $\begin{array}{c}\text { relative } \\
\text { probability } \\
(2)\end{array}$ & $\begin{array}{c}\mathbf{1 9 9 1} \\
\text { probability } \\
(1)\end{array}$ & $\begin{array}{c}\text { relative } \\
\text { probability } \\
\text { (2) }\end{array}$ \\
\hline & & & & & & & & \\
\hline elementary & 0.202 & 9.515 & 0.259 & 4.855 & 0.204 & 4.078 & 0.194 & 3.409 \\
\hline secondary & 0.099 & 4.672 & 0.105 & 1.965 & 0.107 & 2.130 & 0.121 & 2.135 \\
\hline coll / some univ & 0.056 & 2.626 & 0.058 & 1.088 & 0.073 & 1.450 & 0.072 & 1.267 \\
\hline univ degree & 0.021 & 1.000 & 0.053 & 1.000 & 0.050 & 1.000 & 0.057 & 1.000 \\
\hline \multicolumn{9}{|l|}{ Age of Family } \\
\hline$<=26$ & 0.151 & 1.791 & 0.157 & 1.863 & 0.242 & 4.464 & 0.173 & 2.179 \\
\hline $27-34$ & 0.081 & 0.963 & 0.083 & 0.984 & 0.096 & 1.777 & 0.102 & 1.292 \\
\hline $35-44$ & 0.085 & 1.000 & 0.084 & 1.000 & 0.054 & 1.000 & 0.079 & 1.000 \\
\hline $45-54$ & $0.133 *$ & 1.576 & $0.130 *$ & 1.541 & 0.085 & 1.564 & 0.109 & 1.372 \\
\hline $55+$ & $0.161 *$ & 1.906 & $0.133 *$ & 1.588 & 0.029 & 0.534 & 0.023 & 0.291 \\
\hline \multicolumn{9}{|c|}{ Number of Earners/Family Type } \\
\hline lone par/ no earn & 0.935 & 19.338 & 0.928 & 20.610 & 0.912 & 21.755 & 0.699 & 15.364 \\
\hline lone par/ 1 earn & 0.483 & 9.984 & 0.383 & 8.502 & 0.467 & 11.127 & 0.462 & 10.153 \\
\hline two par/ no earn & 0.810 & 16.751 & 0.877 & 19.488 & 0.891 & 21.255 & 0.709 & 15.573 \\
\hline two par/ 1 earn & 0.101 & 2.083 & 0.137 & 3.043 & 0.146 & 3.481 & 0.163 & 3.587 \\
\hline two par/ $2+$ earn & 0.048 & 1.000 & 0.045 & 1.000 & 0.042 & 1.000 & 0.046 & 1.000 \\
\hline \multicolumn{9}{|c|}{ Number of Children } \\
\hline 1 & 0.045 & 1.000 & 0.071 & 1.000 & 0.051 & 1.000 & 0.080 & 1.000 \\
\hline 2 & 0.072 & 1.603 & $0.081 *$ & 1.139 & 0.076 & 1.490 & $0.081 *$ & 1.014 \\
\hline 3 & 0.121 & 2.698 & 0.136 & 1.900 & 0.165 & 3.251 & 0.129 & 1.613 \\
\hline 4 or more & 0.290 & 6.493 & 0.220 & 3.087 & 0.283 & 5.583 & 0.217 & 2.704 \\
\hline
\end{tabular}

1) Evaluated at the mean value of the other variables. This is done by using the weighted sum of the B's for each family of dummy variables, where the weight is the share of the population in that specific category

(2) Relative to the lowest group

* Not significantly different from the reference group used in the regression. 


\section{Appendix Table 3 (cont'd): Relative Probabilities of a Child Being in a Family with a Disposable Income Less than 0.5 Median Disposable Income: Estimated from a Logistic Regression Model \\ Children Aged 7 - 14 years}

\begin{tabular}{|c|c|c|c|c|c|c|c|c|}
\hline \multirow[b]{2}{*}{ Education } & $\begin{array}{c}\mathbf{1 9 7 3} \\
\text { probability } \\
(1)\end{array}$ & $\begin{array}{c}\text { relative } \\
\text { probability } \\
(2)\end{array}$ & $\begin{array}{c}\mathbf{1 9 8 1} \\
\text { probability } \\
(1)\end{array}$ & $\begin{array}{c}\text { relative } \\
\text { probability } \\
(2)\end{array}$ & $\begin{array}{c}\mathbf{1 9 8 8} \\
\text { probability } \\
(1)\end{array}$ & $\begin{array}{c}\text { relative } \\
\text { probability } \\
\text { (2) }\end{array}$ & $\begin{array}{c}1991 \\
\text { probability } \\
(1)\end{array}$ & $\begin{array}{c}\text { relative } \\
\text { probability } \\
(2)\end{array}$ \\
\hline & 0.240 & 23.683 & 0.195 & 6.899 & 0.193 & 6.478 & 0.180 & 4.003 \\
\hline secondary & 0.118 & 11.696 & 0.092 & 3.252 & 0.104 & 3.482 & 0.116 & 2.583 \\
\hline coll / some univ & 0.065 & 6.427 & 0.045 & 1.580 & 0.062 & 2.084 & 0.063 & 1.396 \\
\hline $\begin{array}{l}\text { univ degree } \\
\text { Age of Family }\end{array}$ & 0.010 & 1.000 & 0.028 & 1.000 & 0.030 & 1.000 & 0.045 & 1.000 \\
\hline$<=26$ & 0.198 & 1.779 & 0.209 & 2.977 & 0.243 & 3.478 & 0.241 & 2.704 \\
\hline $27-34$ & 0.096 & 0.864 & 0.094 & 1.333 & 0.099 & 1.418 & 0.095 & 1.072 \\
\hline $35-44$ & 0.111 & 1.000 & 0.070 & 1.000 & 0.070 & 1.000 & 0.089 & 1.000 \\
\hline $45-54$ & 0.142 & 1.278 & 0.099 & 1.410 & 0.092 & 1.312 & 0.086 & 0.961 \\
\hline $55+$ & $0.200 *$ & 1.798 & 0.133 & 1.895 & 0.086 & 1.233 & 0.137 & 1.537 \\
\hline \multicolumn{9}{|c|}{$\frac{\text { Number of Earners/Family }}{\text { Type }}$} \\
\hline lone par/ no earn & 0.902 & 13.094 & 0.903 & 20.798 & 0.889 & 19.628 & 0.764 & 14.616 \\
\hline lone par/ 1 earn & 0.335 & 4.862 & 0.294 & 6.776 & 0.264 & 5.829 & 0.242 & 4.621 \\
\hline two par/ no earn & 0.872 & 12.662 & 0.874 & 20.117 & 0.816 & 18.015 & 0.717 & 13.719 \\
\hline two par/ 1 earn & 0.158 & 2.290 & 0.150 & 3.463 & 0.134 & 2.949 & 0.173 & 3.307 \\
\hline $\begin{array}{l}\text { two par/ } 2+\text { earn } \\
\text { Number of Chilo }\end{array}$ & 0.069 & 1.000 & 0.043 & 1.000 & 0.045 & 1.000 & 0.052 & 1.000 \\
\hline 1 & 0.058 & 1.000 & 0.055 & 1.000 & 0.055 & 1.000 & 0.071 & 1.000 \\
\hline 2 & 0.075 & 1.283 & 0.072 & 1.317 & 0.067 & 1.226 & $0.078 *$ & 1.106 \\
\hline 3 & 0.122 & 2.099 & 0.116 & 2.125 & 0.115 & 2.098 & 0.117 & 1.654 \\
\hline 4 or more & 0.281 & 4.813 & 0.196 & 3.576 & 0.234 & 4.285 & 0.224 & 3.182 \\
\hline
\end{tabular}

1) Evaluated at the mean value of the other variables. This is done by using the weighted sum of the B's for each family of dummy variables, where the weight is the share of the population in that specific category

(2) Relative to the lowest group

* Not significantly different from the reference group used in the regression. 
Changes in the risk of poverty associated with particular family types and labour market characteristics have changed quite substantially since the 1970s. There has been significant compression in the relative risk of poverty between family types largely because the probability of low income among traditionally advantaged groups has risen. For example, the relative advantage for children with university educated parents compared to those with elementary educated parents was reduced from a factor of 10 in 1973 to a factor of 3 in 1991. Unfortunately, this was not because the probability of low income fell significantly among the elementary educated families, rather it rose among the university educated (from $2.1 \%$ in 1973 to $5.7 \%$ in 1991).

The same compression in the relative probabilities is observed for other variables, notably the number of children and family type/number of earners (Appendix Table 3). Again, this compression usually results from a rising probability of low income among the relatively advantaged groups, rather then a decline among the more disadvantaged. For example, the relative position of children in single parent one-earner families to their two parent counterparts was compressed (from a factor of 4.8 in 1973 to 2.8 in 1991) largely because of rising probabilities of low income among two parent one earner families. 15

The probability of low income has risen for many groups, particularly the relatively advantaged groups, over the period. The decomposition conducted in the main text demonstrates the same point; after controlling for demographic changes, the incidence of low income among children is seen to rise. Demographic changes will be seen to have a very large influence on low income, because such changes have been substantial, as noted earlier.

In summary, the probabilities of low income have increased within many groups, and the mix of children among family types has changed substantially over the period. The influence of these changes on the incidence of low income is estimated in the main text.

15 The exception is the probability of low income among single parent/0 earner families. This fell significantly, likely because of the increasing influence of the transfer system. 


\section{Bibliography}

BENGTSON, V. and ACHERBAUM, W., The Changing Contract Across Generations

BETCHERMAN, G. and MORISSETTE, R., 1992, Recent Youth Labour Market Experiences in Canada, Research Paper \# 63, Analytical Studies Branch, Statistics Canada

BLANK, R., ed., 1994, Social Protection vs. Economic Flexibility, Is There a Trade-off, Chicago Press, Chicago

BLANK, R. and CARD, D., 1993, Poverty, Income Distribution and Growth : Are They Still Connected, Brookings Papers on Economic Activity

BOYD and PRYOR, 1989, “The Cluttered Nest : living arrangements of young Canadian adults", Canadian Journal of Sociology, 15:4, pg. 463-79

DAVIS, S., 1992, "Cross-Country Patterns of Change in Relative Wages", National Bureau of Economic Research Working Paper \# 4085

DOOLEY, M., 1993, Women, Children and Poverty in Canada, May, Department of Economics, McMaster University, Mimeo

FREEMAN, 1994, Working Under Different Rules, N.Y. Russell Sage

GOTTSCHALK, P. and DANZIGER, S., 1993, Family Structure, Family Size and Family Income: Accounting for Changes in the Economic Well Being of Children, 1968-1986, in Uneven Tides, Rising Inequality in America, Danziger and Gottschalk, eds

HANRATTY, M. J. and BLANK, R. M., 1992, Down and Out in North America : Recent Trends in Poverty Rates in the United States and Canada, The Quarterly Journal of Economics, February

HAVEMAN, R. and BURON, L., 1993, Escaping Poverty Through Work : The Problem of Low Earnings Capacity on the United States, 1973-88, Review of Income and Wealth, June

HUM, D. and SIMPSON, W., 1991, Income Maintenance, Work Effort, and the Canadian Mincome Experiment, Economic Council of Canada

LOVE, R. and POULIN, S., 1992, "Family Income Inequality in the 1980s", Canadian Economic Observer, September, Statistics Canada, Ottawa

MOFFIT, R. A., 1990, The Distribution of Earnings and the Welfare State, in A Future of Lousy Jobs, G. Burtless, ed., The Brookings Institute, Washington 
MORISSETTE, R., MYLES, J. and PICOT, G., 1994, Earnings Inequality and the Distribution of Working Time in Canada, Canadian Business Economics, Spring

MYLES, J., PICOT, G. and WANNELL, T., 1988, Wages and Jobs in the 1980s : Changing Youth Wages and the Declining Middle, Research Paper \# 17, Analytical Studies Branch, Statistics Canada

MURRAY, C., 1984, Losing Ground, American Social Policy N.Y. Basic Books

OECD, 1993, Earnings Inequality : Changes in the 1980s, in Employment Outlook, Paris

OECD, 1994, "New Orientations for Social Policy”, Social Policy Studies No. 12, Paris

OSBERG, L., 1986, Behavioural Responses in the Context of Socio-Economic Microanalytic Simulation, Research Paper \#1, Analytical Studies Branch Research Paper, Statistics Canada

SARGEANT, T.C., 1995, An Index of the Generosity of Unemployment Insurance, University of British Columbia, June

SHARIF, N. and PHIPPS, S., 1994, "The Challenge of Child Poverty", Canadian Business Economics, Vol. 2, No. 3, Spring

STATISTICS CANADA, 1993, Income Distributions by Size in Canada, Catalogue \#13-207, Statistics Canada

WOLFSON, M., 1986, Stasis Amid Change : Income Inequality in Canada, 1965-1983, Review of Income and Wealth, December

WOLFSON, M. and EVANS, J., 1992, Statistics Canada's Low Income Cut-Offs: Methodological Concerns and Possibilities, Analytical Studies Branch, Statistics Canada 